\title{
Intracellular expression of Tat alters mitochondrial functions in T cells: a potential mechanism to understand mitochondrial damage during HIV-1 replication
}

\author{
Sara Rodríguez-Mora', Elena Mateos', María Moran²,3, Miguel Ángel Martín²,3, Juan Antonio López ${ }^{4}$, \\ Enrique Calvo ${ }^{4}$, María Carmen Terrón ${ }^{5}$, Daniel Luque ${ }^{5}$, Delphine Muriaux ${ }^{6,7}$, José Alcamí ${ }^{1}$, Mayte Coiras ${ }^{1}$ \\ and María Rosa López-Huertas ${ }^{1,6^{*}}$
}

\begin{abstract}
Background: HIV-1 replication results in mitochondrial damage that is enhanced during antiretroviral therapy (ART). The onset of HIV-1 replication is regulated by viral protein Tat, a 101-residue protein codified by two exons that elongates viral transcripts. Although the first exon of Tat (aa 1-72) forms itself an active protein, the presence of the second exon (aa 73-101) results in a more competent transcriptional protein with additional functions.

Results: Mitochondrial overall functions were analyzed in Jurkat cells stably expressing full-length Tat (Tat101) or one-exon Tat (Tat72). Representative results were confirmed in PBLs transiently expressing Tat101 and in HIV-infected Jurkat cells. The intracellular expression of Tat101 induced the deregulation of metabolism and cytoskeletal proteins which remodeled the function and distribution of mitochondria. Tat101 reduced the transcription of the mtDNA, resulting in low ATP production. The total amount of mitochondria increased likely to counteract their functional impairment. These effects were enhanced when Tat second exon was expressed.
\end{abstract}

Conclusions: Intracellular Tat altered mtDNA transcription, mitochondrial content and distribution in CD4+ T cells. The importance of Tat second exon in non-transcriptional functions was confirmed. Tat101 may be responsible for mitochondrial dysfunctions found in HIV-1 infected patients.

Keywords: HIV-1, Tat, Mitochondria, Cytoskeletal rearrangements, Aerobic glycolysis, mtDNA transcription

\section{Background}

Human immunodeficiency virus type 1 (HIV-1) infection is characterized by a progressive depletion of $\mathrm{CD}_{4}{ }^{+}$ $\mathrm{T}$ lymphocytes in the peripheral blood and lymphoid organs which finally leads to the onset of acquired immune deficiency syndrome [1]. HIV-1 replication results in the chronic activation of the immune system and consequently in premature immunosenescence [2]. During normal aging, mitochondrial DNA (mtDNA)

\footnotetext{
*Correspondence: mrlhuertas@isciii.es

1 Unidad de Inmunopatología del SIDA, Centro Nacional de

Microbiología, Instituto de Salud Carlos III, Majadahonda, Madrid, Spain

Full list of author information is available at the end of the article
}

accumulate mutations induced through the direct exposition to reactive oxygen species (ROS) and deficient repair systems $[3,4]$. Accordingly, T CD4+ lymphocytes from naïve HIV-1 infected patients show mtDNA depletion along with impaired activity of the respiratory chain components, enhanced oxidative damage and decrease mitochondrial transmembrane potential $(\Delta \psi \mathrm{m})[5,6]$. These alterations may be explained by a deregulated expression of nuclear and mitochondrial encoded proteins such as Prohibitin, Heat shock protein 60 (Hsp60) and complex-I subunit NDUF6 [7, 8]. Furthermore, it is well-known that the antiretroviral treatment (ART) against HIV-1, in particular nucleoside-analogue inhibitors (NRTIs), induces mitochondrial toxicity $[9,10]$ due to the inhibition of 
mtDNA polymerase $\gamma$ [11]. In summary, HIV-1 infection triggers mitochondria impairment aside from the toxicity of the treatment and therefore it may enhance the susceptibility for the clinical onset of ART side-effects.

HIV-1 Tat is a 101-residue protein codified by two exons that promotes the efficient elongation of the viral transcripts through the binding to RNA polymerase II (RNAPII) complex and the recruitment of cellular elongation factors [12]. The first exon of Tat includes amino acids (aa) 1-72 and encodes an active protein that partially retains the elongation ability of full-length Tat [13]. The second exon is codified by amino acids 73-101 and its expression within the protein results in a more competent transcriptional protein with additional functions independent of transcription such as control of apoptosis $[14,15]$. Tat can be released from infected cells and up-taken by non-infected adjacent cells. Extracellular and intracellular Tat frequently have opposite actions, as Tat expressed inside the host-infected cells can delay apoptosis upon FasL-challenge [14-17], but it is a potent death inductor in its soluble form $[18,19]$. Although loss of $\Delta \psi \mathrm{m}$ and increased levels of ROS has been found after Tat extracellular exposure [20-22], few data are available about the effect of intracellular Tat on mitochondria functions. Our group showed that intracellular Tat deregulated the expression of proteins required for mitochondrial membrane stabilization as HSP and Prohibitin [15].

In this work, we describe the single influence of intracellular HIV-1 Tat protein on mitochondria overall functions in CD4+ T cells, showing that Tat101 remodeled mitochondria distribution and enhanced the mitochondria content probably to compensate the mtDNA transcription impairment. These effects were enhanced when Tat second exon was expressed.

\section{Results}

\section{Tat101 deregulated the expression of cellular proteins} related to metabolism and oxidative stress

To describe the role of Tat on mitochondria, Jurkat cells stably expressing Tat72 (Jurkat-Tat72) or Tat101 (JurkatTat101) protein were used as a proper model of CD4+ $\mathrm{T}$ lymphocytes as previously shown [15]. The proteome of Jurkat-Tat101 and Jurkat-Tat72 was analyzed by liquid chromatography-mass spectrometry (LC-MS)/MS in basal conditions, in comparison with control cells. A comparative analysis of the LC-MS/MS proteome showed that the intracellular expression of Tat101 deregulated the expression of 19 cellular proteins involved in metabolism and control of oxidative stress (Table 1). A total of 14 proteins were up-regulated, representing $73.68 \%$ of the deregulated proteins. To a lower extend, these proteins were also deregulated in Jurkat-Tat72 cells. Proteins with major functions in glycolysis included alpha-enolase (ENO1), glyceraldehyde-3-phosphate dehydrogenase (GAPDH), L-lactate dehydrogenase (LDHB) and pyruvate kinase isozymes M1/M2 (PKM2), which were, respectively 17.9-, -11.4-, 10.4- and 36.8fold expressed in Jurkat-Tat101 cells versus control cells. It was found an overall up-regulation of proteins from the thioredoxin and glutaredoxin redox superfamilies. These proteins included protein disulfide-isomerase (P4HB), thioredoxin domain-containing protein 17 (TXDC17), protein disulfide-isomerase A4 (PDIA4) and SH3 domain-binding glutamic acid-rich-like protein 3 (SH3BGR3), which were, respectively, 2.5-, 2.8-, 5.2-, and 8.4-fold deregulated. Other proteins related to the oxidative metabolism such as superoxide dismutase (SOD1) and peroxiredoxin-1 (PRDX1) were 3.3- and 7.8-fold upregulated in Jurkat-Tat101 cells. Most of these proteins were functionally interconnected as it was observed after analyzing the predicted interactions by STRING database (Fig. 1).

Tat101 increased citrate synthase activity and lactate levels but reduced the activity of respiratory complexes

Citrate synthase levels are routinely used as a marker mitochondrial content [23]. In Jurkat-Tat101 cells, citrate synthase activity increased 4.75 -fold regarding control cells $(p<0.05)$, whereas it increased only 2.75 -fold in Jurkat-Tat72 (Fig. 2a). Although the average amount of mitochondria was increased, the overall production of ATP was significantly reduced in Jurkat-Tat101 cells $(p<0.01)$ (Fig. 2b), suggesting that these mitochondria were not functionally competent. To test this hypothesis, the enzyme activity of complex-I and complex-V of the respiratory chain was measured, using citrate synthase activity to normalize mitochondrial content. Complex-I and complex-V activities were 2.85- and 2.27fold reduced, respectively, in Jurkat-Tat101 $(p<0.05)$. Complex-I and complex-V were only 1.35 - and 1.85 -fold reduced in Jurkat-Tat72, respectively (Fig. 2c).

As the function of complex-I and complex- $\mathrm{V}$ complexes was impaired in Jurkat-Tat101 cells and ATP production was reduced but not completely stopped, aerobic glycolysis was studied as a complementary energy source in Jurkat-Tat101 cells. Aerobic glycolysis is a metabolic program in which the lactate production occurs in the presence of oxygen [24, 25]. Intracellular levels of lactate were measured under aerobic conditions and both JurkatTat101 and Jurkat-Tat72 cells showed a similar increase of 2.0-fold ( $p<0.05)$ (Fig. 2d, left graph). A slight nonsignificant increase of 1.25- and 1.42-fold of lactate levels was found in the culture medium of Jurkat-Tat72 and Jurkat-Tat101 cells, respectively, in comparison to control cells (Fig. 2d, right graph). 
Table 1 Selection of mitochondrial-related proteins which showed at least a $\mathbf{2} \mathbf{2 . 0}$-fold deregulation in Jurkat-Tat101 versus control cells

\begin{tabular}{|c|c|c|c|c|c|c|}
\hline Gene & Protein & $\begin{array}{l}\text { Tat72 vs } \\
\text { TetOff }\end{array}$ & $\begin{array}{l}\text { Tat101 vs } \\
\text { TetOff }\end{array}$ & Biological process & Peptide sequence & X-corr \\
\hline PKM2 & $\begin{array}{l}\text { Pyruvate kinase isozymes } \\
\text { M1/M2 }\end{array}$ & 6.5 & 36.8 & Glycolysis & $\begin{array}{l}\text { APIIAVTRNPQTAR } \\
\text { EAEAAIYHLQLFEELRR } \\
\text { FGVEQDVDMVFASFIR } \\
\text { GSGTAEVELKK } \\
\text { IYVDDGLISLQVK } \\
\text { KGVNLPGAAVDLPAVSEKDIQDLK } \\
\text { LDIDSPPITAR } \\
\text { RFDEILEASDGIMVAR } \\
\text { SVETLKEMIK } \\
\text { TATESFASDPILYRPVAVALDTK } \\
\text { TATESFASDPILYRPVAVALDTKGPEIR }\end{array}$ & $\begin{array}{l}2.65 \\
1.81 \\
2.90 \\
2.06 \\
1.88 \\
3.72 \\
2.01 \\
3.16 \\
1.96 \\
2.80 \\
3.18\end{array}$ \\
\hline $\mathrm{LDHB}$ & $\begin{array}{l}\text { L-lactate dehydrogenase } \\
\text { (B chain) }\end{array}$ & -0.9 & 10.4 & Glycolysis & $\begin{array}{l}\text { IVADKDYSVTANSK } \\
\text { LKDDEVAQLKK } \\
\text { SADTLWDIQK } \\
\text { SADTLWDIQKDLKDL }\end{array}$ & $\begin{array}{l}2.07 \\
2.26 \\
2.05 \\
2.08\end{array}$ \\
\hline SH3BGRL3 & $\begin{array}{l}\text { SH3 domain-binding } \\
\text { glutamic acid-rich-like } \\
\text { protein } 3\end{array}$ & 9.9 & 8.1 & Oxidative stress & $\begin{array}{l}\text { IQYQLVDISQDNALRDEMR } \\
\text { VYSTSVTGSR }\end{array}$ & $\begin{array}{l}3.12 \\
2.48\end{array}$ \\
\hline PRDX1 & Peroxiredoxin-1 & 7.9 & 7.8 & Oxidative stress & $\begin{array}{l}\text { QGGLGPMNIPLVSDPKR } \\
\text { QITVNDLPVGR } \\
\text { TIAQDYGVLKADEGISFR }\end{array}$ & $\begin{array}{l}1.78 \\
2.06 \\
2.95\end{array}$ \\
\hline PDIA4 & $\begin{array}{l}\text { Protein disulfide-isomerase } \\
\text { A4 }\end{array}$ & 0.7 & 5.2 & Oxidative stress & $\begin{array}{l}\text { FDVSGYPTIK } \\
\text { FDVSGYPTLK } \\
\text { IDATSASVLASR } \\
\text { MDATANDVPSDR } \\
\text { VDATAETDLAKR }\end{array}$ & $\begin{array}{l}1.98 \\
1.98 \\
2.51 \\
1.75 \\
1.83\end{array}$ \\
\hline TKT & Transketolase & -1.2 & 4.9 & Energy metabolism & $\begin{array}{l}\text { ILATPPQEDAPSVDIANIR } \\
\text { KAYGQALAK } \\
\text { MFGIDRDAIAQAVR }\end{array}$ & $\begin{array}{l}1.80 \\
2.29 \\
2.71\end{array}$ \\
\hline TXNDC17 & $\begin{array}{l}\text { Thioredoxin domain-con- } \\
\text { taining protein } 17\end{array}$ & 0.9 & 2.8 & Oxidative stress & YEEVSVSGFEEFHR & 1.77 \\
\hline SOD1 & Superoxide dismutase & 0.4 & 3.3 & Oxidative stress & $\begin{array}{l}\text { TLWHEKADDLGK } \\
\text { TLWHEKADDLGKGGNEESTK }\end{array}$ & $\begin{array}{l}1.76 \\
3.07\end{array}$ \\
\hline ALDOA & $\begin{array}{l}\text { Fructose-bisphoshate } \\
\text { aldolase A }\end{array}$ & 8.9 & 2.7 & Glycolysis & $\begin{array}{l}\text { AAQEEYVKR } \\
\text { GILAADESTGSIAK } \\
\text { GILAADESTGSIAKR } \\
\text { IGEHTPSALAIMENANVLAR } \\
\text { IVAPGKGILAADESTGSIAK } \\
\text { IVAPGKGILAADESTGSIAKR } \\
\text { LQSIGTENTEENR }\end{array}$ & $\begin{array}{l}1.88 \\
3.03 \\
2.61 \\
2.69 \\
3.80 \\
3.91 \\
2.41\end{array}$ \\
\hline $\mathrm{P} 4 \mathrm{HB}$ & Protein disulfide-isomerase & 1.5 & 2.5 & Oxidative stress & MDSTANEVEAVKVHSFPTLK & 2.02 \\
\hline GYS1 & Glycogen synthase, muscle & 0.9 & 2.5 & Glycogenesis & $\begin{array}{l}\text { LSDLLDWK } \\
\text { TQVELLEAPTPALKR } \\
\text { VGGIYTVLQTK }\end{array}$ & $\begin{array}{l}1.79 \\
1.94 \\
1.87\end{array}$ \\
\hline TPM4 & Tropomyosin alpha-4 & 9.9 & 2.2 & Oxidative stress & KIQALQQQADEAEDR & 2.13 \\
\hline TALDO1 & Transaldolase & 0.6 & 2.2 & Energy metabolism & WLHNEDQMAVEK & 2.15 \\
\hline PEBP1 & $\begin{array}{l}\text { Phosphatidylethanola- } \\
\text { mine-binding protein }\end{array}$ & 0.0 & 2.2 & Oxidative stress & $\begin{array}{l}\text { LYEQLSGK } \\
\text { WSGPLSLQEVDEQPQHPLHVTYAGAA }\end{array}$ & $\begin{array}{l}1.79 \\
2.68\end{array}$ \\
\hline PARK7 & Protein DJ-1 & 1.8 & -2.0 & $\begin{array}{l}\text { Autophagy } \\
\text { Fusion } \\
\text { Morphogenesis }\end{array}$ & $\begin{array}{l}\text { GAEEMETVIPVDVMR } \\
\text { GAEEMETVIPVDVMRR }\end{array}$ & $\begin{array}{l}2.08 \\
2.00\end{array}$ \\
\hline PGK1 & Phosphoglycerate kinase 1 & 1.3 & -2.7 & Glycolysis & $\begin{array}{l}\text { AHSSMVGVNLPQK } \\
\text { LGDVYVNDAFGTAHR } \\
\text { VDFNVPMKNNQITNNQR } \\
\text { VLPGVDALSNI }\end{array}$ & $\begin{array}{l}1.81 \\
2.60 \\
2.00 \\
1.96\end{array}$ \\
\hline TPI1 & $\begin{array}{l}\text { Triosephosphate isomerase } \\
\text { isoform } 1\end{array}$ & -5.3 & -3.0 & $\begin{array}{l}\text { Glycolysis gluconeo- } \\
\text { genesis }\end{array}$ & $\begin{array}{l}\text { SNVSDAVAQSTR } \\
\text { WVLAYEPVWAIGTGK }\end{array}$ & $\begin{array}{l}2.95 \\
2.65\end{array}$ \\
\hline
\end{tabular}


Table 1 continued

\begin{tabular}{|c|c|c|c|c|c|c|}
\hline Gene & Protein & $\begin{array}{l}\text { Tat72 vs } \\
\text { TetOff }\end{array}$ & $\begin{array}{l}\text { Tat101 vs } \\
\text { TetOff }\end{array}$ & Biological process & Peptide sequence & X-corr \\
\hline GAPDH & $\begin{array}{l}\text { Glyceraldehyde-3-phos- } \\
\text { phate dehydrogenase }\end{array}$ & -10.8 & -11.4 & Glycolysis & $\begin{array}{l}\text { GALQNIIPASTGAAK } \\
\text { IKWGDAGAEYWESTGVFTTMEK } \\
\text { LISWYDNEFGYSNR } \\
\text { VGVNGFGR } \\
\text { WVDLMAHMASKE } \\
\text { WGDAGAEYWESTGVFTTMEK }\end{array}$ & $\begin{array}{l}1.81 \\
2.17 \\
3.07 \\
2.09 \\
2.87 \\
2.53\end{array}$ \\
\hline PDIA3 & $\begin{array}{l}\text { Protein disulfide-isomerase } \\
\text { A3 }\end{array}$ & & -11.9 & Oxidative stress & $\begin{array}{l}\text { DGEEAGAYDGPR } \\
\text { EATNPPVIQEEKPK } \\
\text { ELSDFISYLQR } \\
\text { GFPTIYFSPANK } \\
\text { IFRDGEEAGAYDGPR } \\
\text { KYEGGRELSDFISYLQR } \\
\text { LSKDPNIVIAK } \\
\text { MDATANDVPSPYEVR } \\
\text { QAGPASVPLR } \\
\text { QAGPASVPLRTEEEFKK } \\
\text { RLAPEYEAAATR } \\
\text { TADGIVSHLKK } \\
\text { YGVSGYPTLK }\end{array}$ & $\begin{array}{l}2.09 \\
2.30 \\
2.43 \\
2.34 \\
3.09 \\
2.91 \\
2.14 \\
2.62 \\
2.59 \\
1.82 \\
2.68 \\
2.68 \\
2.05\end{array}$ \\
\hline
\end{tabular}

Proteins were detected by mass spectrometry in total protein extracts. All peptides detected showed $95 \%$ probability for protein expression and a minimum crosscorrelation (X-Corr) value of 1.75

\section{Enhanced ROS production was counteracted by glutathione system in Jurkat-Tat cells}

A enhanced production of ROS in productively and latently HIV-1 infected CD4+ $\mathrm{T}$ cells has been described [5]. Intracellular levels of ROS were measured using dichlorofluorescein diacetate (DCF-DA) staining method [26]. Immunofluorescence analysis showed that $35.0 \%$ of JurkatTat101 cells showed high DCF-DA signal, whereas both Jurkat-Tat72 and control cells showed only $15 \%$ of highly stained cells (Fig. 3a). Acquisition conditions remained and a representative field of living Jurkat-Tat72 and JurkatTat101 is shown. Similarly, flow cytometry quantification of the geometry mean (G-mean) of green fluorescence increased 1.8-fold in Jurkat-Tat101 and 1.4-fold in JurkatTat72 cells, regarding control cells $(p<0.01)$ (Fig. 3b).

Glutathione is an abundant antioxidant that mostly exits in its reduced form (GSH). A small percentage of the glutathione is oxidized (GSSG) and acts as an indicator of oxidative stress. The intracellular levels of GHS and GSSG were enhanced, respectively 2.2-fold and a 1.8fold in Jurkat-Tat101 ( $p<0.005$ and $p<0.05)$ (Fig. 3c). In Jurkat-Tat72 cells, the increase of glutathione levels was lower than in Jurkat-Tat101 cells and did not reach statistical significance. The GSH/GSSG ratio that measures the cellular oxidative stress [27] remained unaltered in Jurkat cells expressing any isoform of Tat protein.

\section{Intracellular expression of Tat101 increased basal apoptosis}

The intracellular expression of Tat101 protein delays Fas-mediated apoptosis during HIV-1 infection in
CD4+ T lymphocytes [15]. In this work, we show that the percentage of cells displaying a typical apoptotic phenotype, i.e. morphological disintegration and bubbling of the plasma membrane, increased 2.0-fold in Jurkat-Tat101 cells and to a lesser extent also in JurkatTat72 cells, vs control cells (Fig. 4a). It was observed in basal conditions and in the absence of activation or death stimuli. Selected cells with representative living and apoptotic phenotypes are shown in Fig. 4b. Activation of the effector caspase-3/-7 under basal conditions correlated with apoptotic phenotypes and it was 1.8- and 2.0-fold higher in Jurkat-Tat72 and JurkatTat101 cells, respectively, than in control cells (Fig. 4c) $(p<0.05)$.

Apoptosis commitment was measured by quantifying externalization of phosphatidylserine (PS) in Annexin$\mathrm{V}$ stained cells and subsequent flow cytometry analysis, showing a 1.4-fold increase in Jurkat-Tat101 versus control cells $(p<0.05)$ (Fig. 4d). As increased ROS production occurred occurs during cell death, co-localization of intracellular ROS and PS externalization was studied in control and Jurkat-Tat expressing cells doubled stained with DCF-DA and Annexin-V (Fig. 4e). Around $50 \%$ of apoptosis-committed cells expressed intracellular ROS (Fig. 4e, left panel). However, G-mean of green fluorescence increased 1.8-fold in Jurkat-Tat101 cells doubly stained for ROS and apoptosis, regarding control cells $(p<0.01)$ (Fig. 4e, right panel). These data support the enhancement of intracellular ROS and apoptosis independently showed in Figs. 3 and 4 (panels from a to d), respectively. 


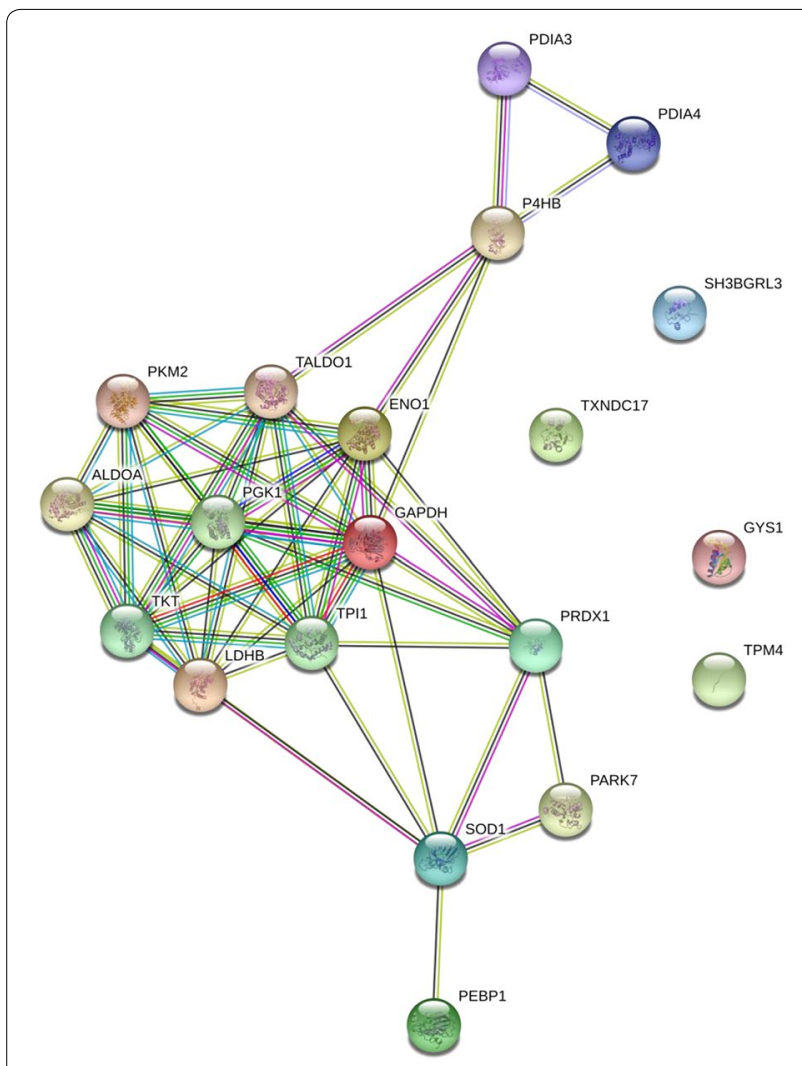

Fig. 1 Network of predicted interactions between mitochondriarelated proteins deregulated in Jurkat-Tat101. Medium confidence score level was 0.400. Data supporting protein-protein interactions derived from experimental studies (dark purple lines), homology (light purple lines), databases (light blue lines), text mining (light green lines), concurrence (dark blue lines) and co-expression (black lines). Node colour is arbitrary. Differences in protein levels are specified in Table 1

Tat101 reduced the transcription of mtDNA encoded genes A unique feature of mitochondria is that they contain their own 16-kb genome that encodes mitochondria components including 13 subunits of the mitochondria respiratory chain essential for the mitochondrial oxidative phosphorylation (OXPHOS) [28, 29]. The transcription of six mtDNA encoded genes was studied in Jurkat-Tat expressing cells (Fig. 5a). These genes included components of the respiratory chain complex-I, complex-III and complex-IV and were NADH-ubiquinone oxidoreductase chain 2 (MTND-2), NADH-ubiquinone oxidoreductase chain 5 (MTND-5), NADH-ubiquinone oxidoreductase chain 6 (MTND-6), cytochrome $c$ oxidase subunit 2 (COX-II), cytochrome $c$ oxidase subunit 3 (MTCO-3), and cytochrome $b$ (MT-CYB). The intracellular expression of Tat101 protein resulted in a significant reduction of more than 6.0-fold in both COX-II and MTND-2 mRNA levels $(p<0.005)$ (Fig. 5a). In Jurkat-Tat72 cells, COX-II and MTND-2 mRNA levels were 3.0 -fold reduced $(p<0.05)$. Although to a lower extend, the expression of other mtDNA encoded genes were also significantly reduced in Jurkat-Tat101. MTND-5, MTND-6, MT-CYB andMTCO-3 mRNAs levels were around 1.5-fold reduced in Jurkat Tat-101 cells $(p<0.005$ and $p<0.001)$ but not in Jurkat-Tat72 cells (Fig. 5a). These data show the down-regulation of mtDNA transcription.

The control of gene expression from mtDNA is directed by nuclear-encoded genes as respiratory factor 1 (NRF-1) and mitochondrial transcription factor A (TFAM) [30]. TFAM mRNA expression was 1.75-fold reduced in Jurkat-Tat101 cells (Fig. 5b) $(p<0.05)$. No significant differences were found in the expression of NRF-1 mRNA in Jurkat-Tat101 cells but the levels of NRF-1 mRNA were slightly enhanced in Jurkat-Tat72cells (Fig. 5b). mRNAs levels of nuclear-encoded genes involved in mitochondrial fusion and fission were analyzed and there were not significant changes in the expression of MFN2 and DNML1 mRNAs (Fig. 5c).

\section{Intracellular Tat101 enhanced the expression of nuclear-encoded mitochondrial genes}

Intracellular Tat101 protein is known to profoundly deregulate gene expression in $\mathrm{T}$ lymphocytes [14, 31]. Therefore the effect of Tat101 protein in the transcription of nuclear-encoded genes required for mitochondria functions was intensely described. A commercial RT-PCR-based array was used to compare the expression of 84 mitochondrial genes, which were nuclearencoded, in Jurkat-Tat101 cells versus control cells. Table 2 shows $C_{\mathrm{T}}$ values and the relative expression of each gene in Jurkat-Tat101 versus control cells after normalizing to the housekeeping gene expressions and analyzing with the $2^{-\Delta \Delta C t}$ formula. Genes showing $C_{T}$ values equal or higher than 30 cycles or undetermined were not considered for additional analysis and therefore only the expression of 77 genes was studied. The expression levels of 67 genes were increased at least +1.5 -fold in Jurkat-Tat101 cells, suggesting a generalized up-regulation of mitochondrial-related genes. These genes represent $88.5 \%$ of the mitochondrial genes studied. A higher cutoff of $\mp 2.0$-fold change yield 17 genes upregulated in Jurkat-Tat101 cells (Fig. 6a). There was an enhanced expression of eight members from mitochondrial solute carrier family 25 (SLC25), a superfamily of proteins that shuttle metabolites, nucleotides, and cofactors through the mitochondrial inner membrane including the exchange of cytoplasmic ADP with mitochondrial ATP [32]. For example, levels of SLC25A23 and SLC25A19 increased 2.43- and 3.28-fold, respectively. Other mitochondrial transporters deregulated included metaxin 2 (MTX2), involved in importing proteins into mitochondria [33], uncoupling protein 3 (UCP3), a 

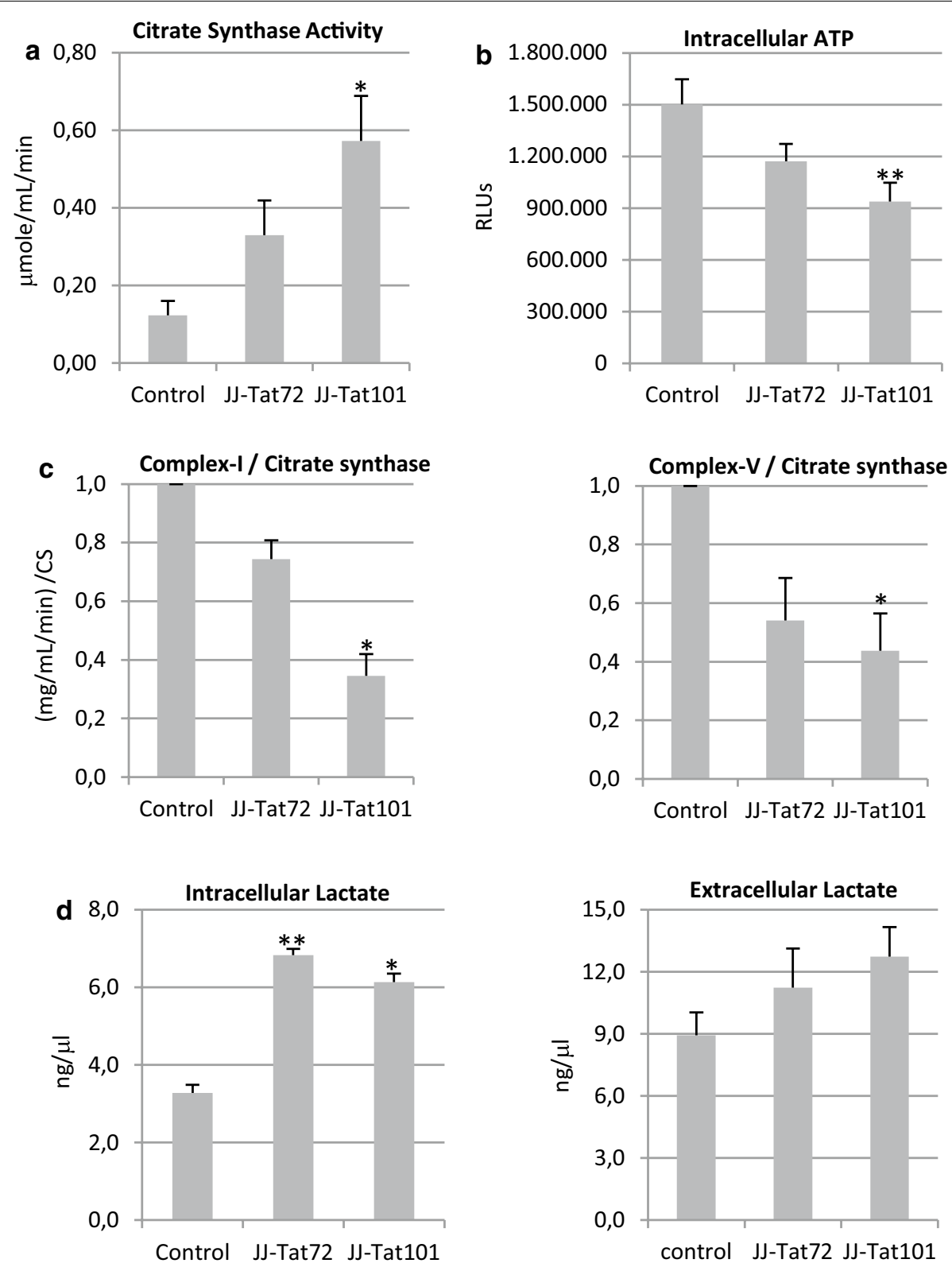

Fig. 2 Quantification of citrate synthase activity, mitochondria respiratory capacity and lactate levels in Jurkat-Tat 101 cells. a Activity of the citrate synthase measured with commercial enzymatic assays in Jurkat-Tat72 (JJ-Tat72), Jurkat-Tat101 (JJ-Tat101) vs control cells. One citrate unit is equivalent to a $\mu \mathrm{mole} / \mathrm{mL} / \mathrm{min}$. b ATP production was measured using a chemiluminescence-based assay. c Activity of the complex-I and complex-V of the respiratory chain was measured in Jurkat-Tat72, Jurkat-Tat 101 and control cells in $\mathrm{mg} / \mathrm{mL} / \mathrm{min}$ and it was normalized according to mitochondria amount indirectly measured as the activity of the citrate synthase enzyme. $\mathbf{d}$ Lactate levels were measured in intracellular and supernatant samples and concentration was expressed in $\mathrm{ng} / \mu \mathrm{l}$ (left and right panels, respectively) from Jurkat-Tat72, Jurkat-Tat101 vs control cells. All data shown are media and standard error of the mean (SEM) from at least three independent experiments. Statistical significance was calculated by Kruskal-Wallis test and post hoc multiple comparisons were performed with Dunn's multiple comparison analysis $\left({ }^{*} p<0.05\right.$ and ${ }^{* *} p<0.01$ vs control)

proton transporter resulting in OXPHOS uncoupling also known as SLC25a9 [34], and translocase of inner mitochondrial membrane 9 (TIMM9), a chaperone involved in the import of transmembrane proteins [35], which were respectively $3.68-, 2.69$ - and 2.23 -fold enhanced.
The functional interconnection of these proteins was predicted in STRING database and is shown in Fig. 6b. These data suggest an increased expression of nuclearencoded mitochondrial genes in Jurkat-Tat101 cells and confirm proteome results showed in Table 1 and Fig. 1. 


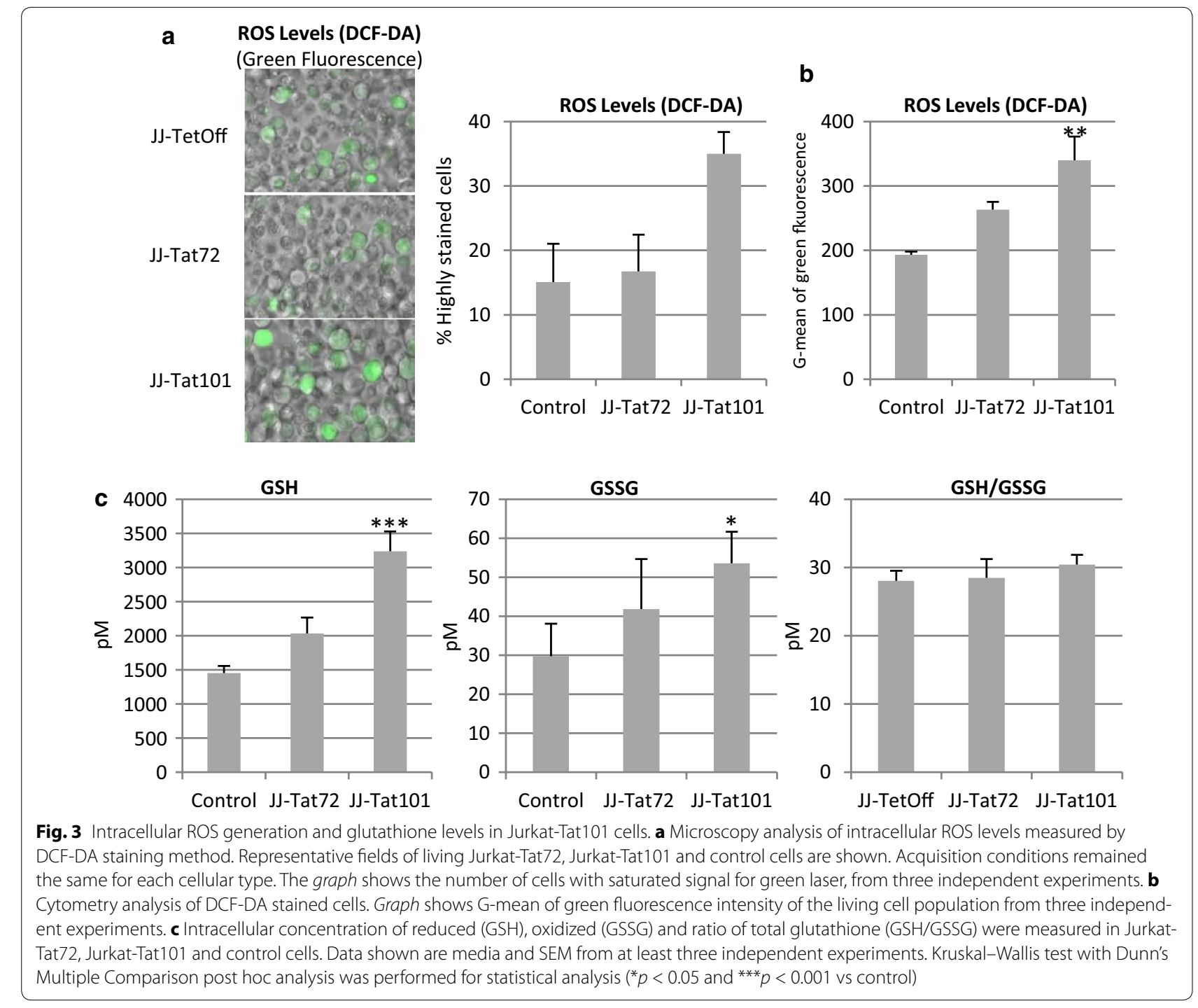

\section{Intracellular Tat101 deregulated the expression}

\section{of cytoskeleton proteins and activated small GTPases}

The interactions between mitochondria and the cytoskeleton influence mitochondrial functions including respiratory activity, fusion/fission processes and ROS biogenesis $[36,37]$. Therefore, the expression of cytoskeleton-related proteins was analyzed by LC-MS/MS and predicted protein interactions were analyzed by STRING database (Fig. 7a). Jurkat-Tat101 cells, and to a lesser extent JurkatTat72 cells, showed the deregulation of 20 cytoskeletonrelated proteins (Table 3). Only five deregulated proteins were tubulin-related. Fifteen actin-related proteins were altered in Jurkat-Tat101 cells. Three of these proteins were involved in small-GTPase signal transduction, including Rho GDP-dissociation inhibitor 2 (ARHGDIB) and GDP dissociation inhibitor beta protein (GDI2), which were -10.0 - and +2.0 -fold deregulated. Furthermore, the activation of RhoA and Rac1 GTPase increased 22.38and 4.67-fold in Jurkat-Tat101 $(p<0.005)$ but not in Jurkat-Tat72 cells (Fig. 7b), in comparison to control cells. Non-significant differences were found in the activation of Cdc42 (Fig. 7c). Finally, cells were stained with an antibody against tubulin to elucidate the cellular shape. Most Jurkat-Tat101 cells showed polarized shape, whereas nonpolarized and typically round-shape lymphocytes were observed in Jurkat-Tat72 and control cells (Fig. 7d). The analysis of migration ability showed that Jurkat-Tat101 cells migrated spontaneously 1.5 -fold more than JurkatTat72 and control cells (Fig. 7e).

\section{Intracellular Tat101 increased mitochondrial amount and polarized its distribution}

Because mitochondria are transported to the uropod to ensure the high ATP demand required for lymphocyte 


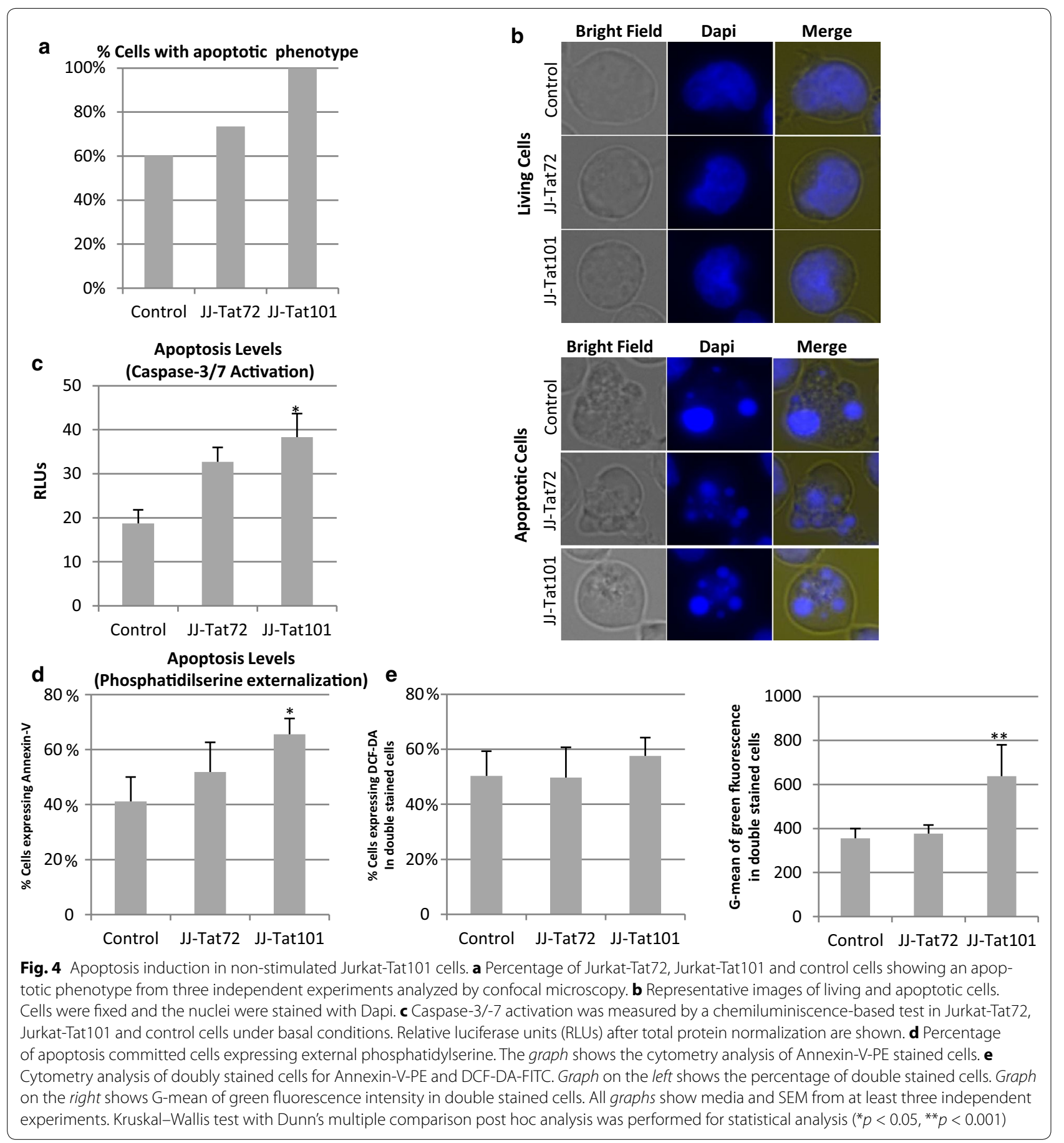

migration [38-40] and Jurkat-Tat101 cells showed an overall cellular polarized shape, the distribution of the mitochondria network was studied. The mitochondria network of Jurkat-Tat101 and control cells was analyzed after incubating with Mitotracker and DAPI. Two different phenotypes, which included a homogeneous and a polarized distribution of the mitochondria network, were identified (Fig. 8a). The overall presence of the polarized phenotype increased up to $50 \%$ in Jurkat-Tat101 cells whereas in control cells reached $9.5 \%$. These phenotypes corresponding to homogeneous and polarized distribution of the mitochondria network were also identified in Jurkat-Tat101 cells by electron microscopy (Fig. 8b). The re-distribution of mitochondria at one edge of the cell 

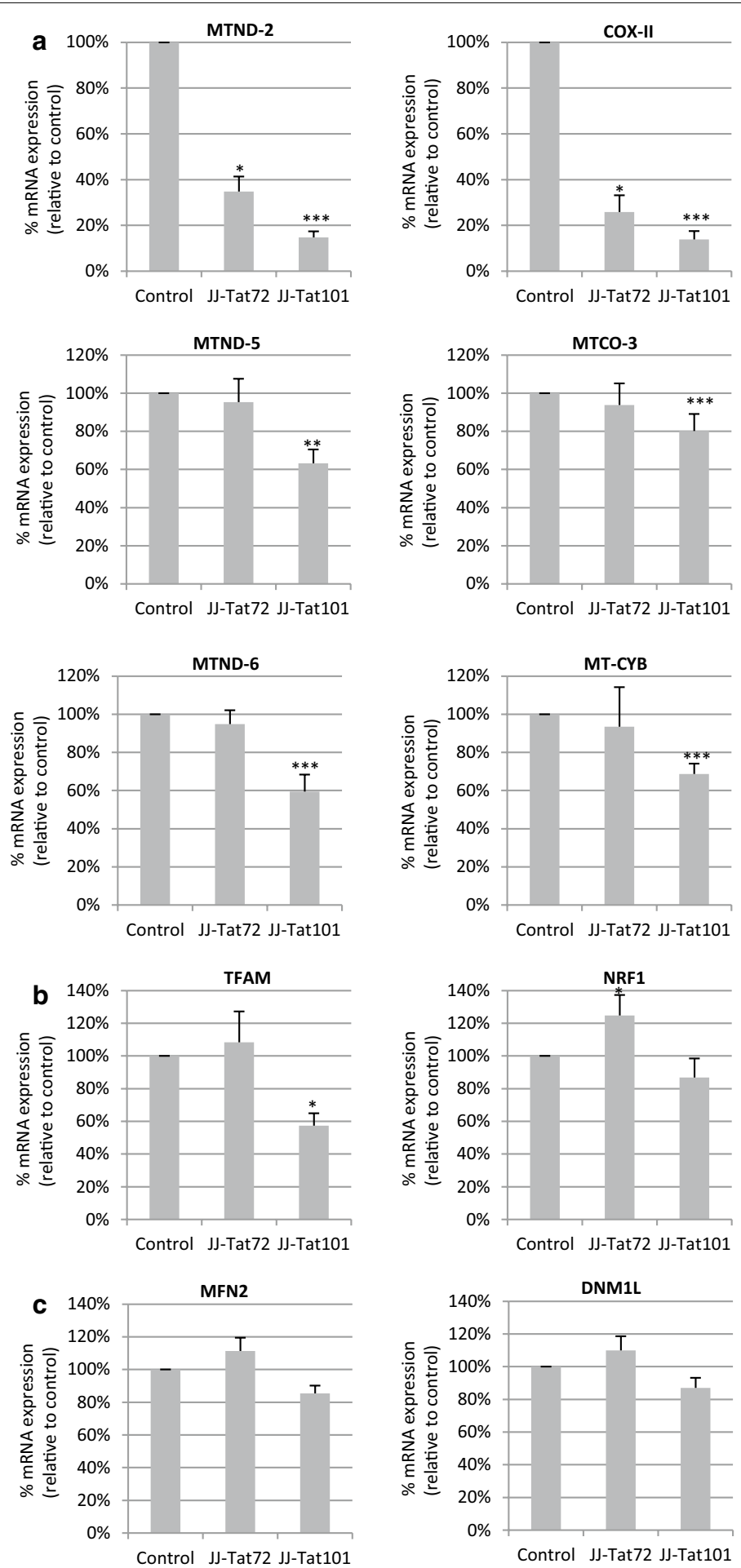

Fig. 5 Effect of Tat on the transcription of mt-DNA and fusion/fission genes. a qPCR analysis of mRNAs levels from the mtDNA-encoded genes COX-II, MTND-2, MTND-5, MTND-6, MT-CYB and MTCO-3. b qRT-PCR analysis of mRNAs levels from nuclear DNA-encoded genes TFAM and NRF1. c qRT-PCR analysis of nuclear-encoded mRNAs from MFN2 and DNM1 Lenes, which are involved in mitochondria fusion and fission, respectively. Total mRNA from control cells, Jurkat-Tat72, and Jurkat-Tat101 cells was analyzed. Nuclear S18 mRNA expression was used as house-keeping gene. All data shown are media and SEM from at least three independent experiments. Statistical significance was calculated by Kruskal-Wallis test with Dunn's multiple comparison post hoc analysis $\left({ }^{*} p<0.05,{ }^{* *} p<0.01{ }^{* * *} p<0.001\right.$ vs control) 
Table $2 \mathrm{C}_{\mathrm{T}}$ and fold expression of mitochondrial nuclear-encoded genes in Jurkat-Tat101 cells

\begin{tabular}{|c|c|c|c|c|c|c|c|}
\hline \multirow[t]{2}{*}{ Gene } & \multicolumn{2}{|l|}{$C_{T}$} & \multirow{2}{*}{$\begin{array}{l}\text { Fold of expression } \\
\text { JJ-Tat } 101 / J J-c o n t r o l\end{array}$} & \multirow[t]{2}{*}{ Gene } & \multicolumn{2}{|l|}{$C_{T}$} & \multirow{2}{*}{$\begin{array}{l}\text { Fold of expression } \\
\text { JJ-Tat } 101 / J J-c o n t r o\end{array}$} \\
\hline & JJ-control & JJ-Tat101 & & & JJ-control & JJ-Tat101 & \\
\hline AIFM2 & 26.97 & 29.28 & 0.85 & SLC25A17 & 20.72 & 21.95 & 2.05 \\
\hline AIP & 19.44 & 20.72 & 1.74 & SLC25A19 & 21.54 & 22.58 & 3.28 \\
\hline BAK1 & 22.30 & 23.80 & 1.49 & SLC25A2 & 28.58 & 28.95 & 1.90 \\
\hline $\mathrm{BBC} 3$ & 28.93 & 30.27 & 1.66 & SLC25A20 & 22.77 & 23.92 & 1.68 \\
\hline $\mathrm{BCL} 2$ & 23.63 & 24.71 & 2.00 & SLC25A21 & 27.02 & 28.34 & 1.87 \\
\hline BCL2L1 & 22.90 & 24.42 & 1.47 & SLC25A22 & 23.78 & 24.95 & 2.05 \\
\hline BID & 17.96 & 19.14 & 1.86 & SLC25A23 & 25.51 & 26.55 & 2.43 \\
\hline BNIP3 & 18.59 & 19.68 & 1.98 & SLC25A24 & 21.17 & 21.96 & 2.17 \\
\hline CDKN2A & Undetermined & Undetermined & 1.83 & SLC25A25 & 23.91 & 24.87 & 1.00 \\
\hline $\operatorname{cox} 10$ & 23.44 & 24.64 & 2.10 & SLC25A27 & 37.15 & 37.16 & 4.19 \\
\hline $\operatorname{cox} 18$ & 23.24 & 24.24 & 1.21 & SLC25A3 & 16.89 & 17.98 & 1.97 \\
\hline CPT1B & 30.36 & 32.16 & 1.61 & SLC25A30 & 23.34 & 24.41 & 2.00 \\
\hline CPT2 & 21.88 & 23.27 & 2.03 & SLC25A31 & 32.62 & 32.78 & 3.77 \\
\hline DNM1L & 20.42 & 21.47 & 1.58 & SLC25A37 & 21.47 & 22.65 & 1.86 \\
\hline FIS1 & 19.89 & 21.31 & 2.03 & SLC25A4 & 21.93 & 22.96 & 2.06 \\
\hline TIMM10B & 21.92 & 22.98 & 1.73 & SLC25A5 & 16.59 & 18.12 & 1.45 \\
\hline GRPEL1 & 19.53 & 20.81 & 1.80 & SOD1 & 16.03 & 17.40 & 1.63 \\
\hline HSP90AA1 & 15.48 & 16.70 & 1.80 & SOD2 & 19.48 & 20.69 & 1.82 \\
\hline HSPD1 & 16.17 & 17.39 & 2.13 & STARD3 & 23.29 & 24.53 & 1.78 \\
\hline IMMP1L & 20.91 & 21.90 & 1.52 & $\mathrm{TAZ}$ & 21.59 & 23.00 & 1.59 \\
\hline IMMP2L & 22.01 & 23.48 & 1.99 & TIMM10 & 17.79 & 19.19 & 1.59 \\
\hline LRPPRC & 19.33 & 20.41 & 1.97 & TIMM17A & 19.38 & 20.67 & 1.71 \\
\hline MFN1 & 21.42 & 22.52 & 1.84 & TIMM17B & 20.85 & 22.26 & 1.59 \\
\hline MFN2 & 21.75 & 22.95 & 1.85 & TIMM22 & 22.65 & 23.73 & 1.99 \\
\hline MIPEP & 23.34 & 24.52 & 1.85 & TIMM23 & 19.48 & 20.69 & 1.82 \\
\hline MPV17 & 21.24 & 22.43 & 1.61 & TIMM44 & 21.38 & 22.68 & 1.70 \\
\hline MSTO1 & 22.30 & 23.68 & 1.59 & TIMM50 & 19.19 & 20.29 & 1.96 \\
\hline MTX2 & 20.15 & 21.56 & 3.68 & TIMM8A & 20.40 & 21.65 & 1.77 \\
\hline NEFL & 32.20 & 32.39 & 1.97 & TIMM8B & 17.59 & 18.94 & 1.65 \\
\hline OPA1 & 20.33 & 21.43 & 2.62 & TIMM9 & 24.46 & 25.37 & 2.23 \\
\hline PMAIP1 & 21.54 & 22.22 & 1.73 & TOMM20 & 17.88 & 19.14 & 1.75 \\
\hline RHOT1 & 20.37 & 21.66 & 1.72 & TOMM22 & 17.92 & 19.41 & 1.50 \\
\hline RHOT2 & 21.68 & 22.97 & 1.73 & TOMM34 & 20.85 & 22.18 & 1.67 \\
\hline SFN & 25.74 & 27.02 & 1.95 & TOMM40 & 20.69 & 22.37 & 1.31 \\
\hline SH3GLB1 & 20.52 & 21.63 & 1.47 & TOMM40L & 23.80 & 24.95 & 1.89 \\
\hline SLC25A1 & 19.77 & 21.29 & 1.04 & TOMM70A & 19.70 & 20.78 & 1.99 \\
\hline SLC25A10 & 25.56 & 27.57 & 1.84 & TP53 & 22.63 & 23.91 & 1.73 \\
\hline SLC25A12 & 21.66 & 22.85 & 2.02 & TSPO & 30.82 & 34.61 & 0.31 \\
\hline SLC25A13 & 24.15 & 25.21 & 1.94 & UCP1 & 26.98 & 28.95 & 1.07 \\
\hline SLC25A14 & 22.35 & 23.46 & 1.83 & UCP2 & 19.92 & 21.44 & 1.46 \\
\hline SLC25A15 & 21.18 & 22.38 & 1.99 & UCP3 & 27.19 & 27.84 & 2.69 \\
\hline SLC25A16 & 21.68 & 22.76 & 1.80 & UXT & 18.46 & 19.73 & 1.74 \\
\hline
\end{tabular}

was detected in $84.0 \%$ of Jurkat-Tat101 cells but only in $36 \%$ of control cells. However, ultrastructure changes were not detected and in both types of cells the overall size and shape of mitochondria were similar, showing mitochondria with normal crista, enlarged shape and double organelle membrane.

Then, average amount of mitochondria was quantified in Tat expressing cells. Jurkat-Tat101 and Jurkat-Tat72 

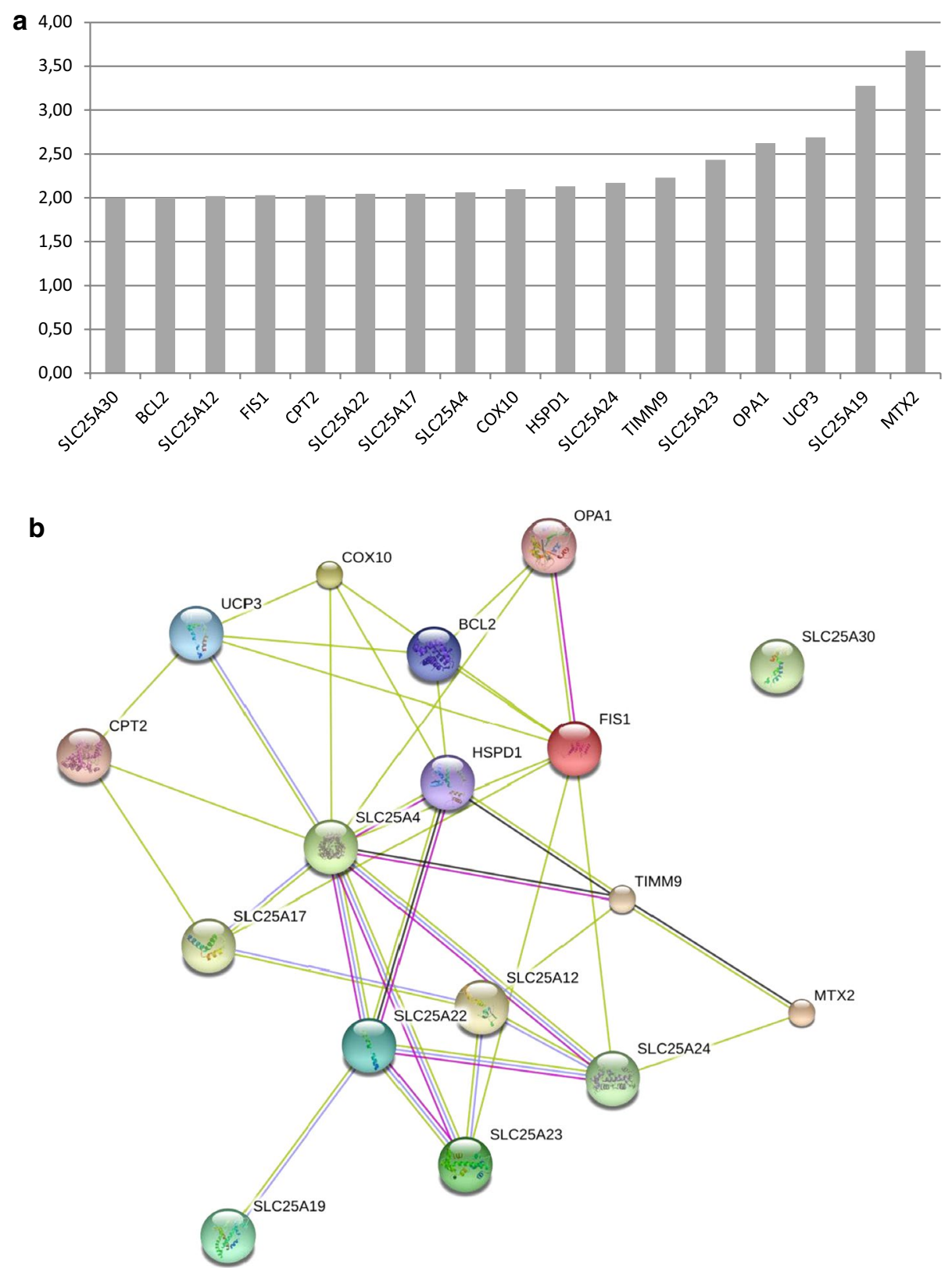

Fig. 6 Expression of an array of nuclear-encoded genes related to mitochondria in Jurkat-Tat101 cells. The expression of mitochondrial genes encoded by nuclear DNA was analyzed by qRT-PCR in total RNA from Jurkat-Tat101 cells versus controls cells, using RT $^{2}$ Profiler ${ }^{\text {TM }}$ PCR Array Human Mitochondria. a Relative expression levels of mitochondrial-related genes deregulated at least \pm 2.0 -fold in Jurkat-Tat 101 cells versus control cells. Table 2 includes the relative gene expression levels of 84 mitochondrial-genes included in the analysis. b Network of predicted interactions between mitochondria-related genes deregulated \pm 2.0 -fold in Jurkat-Tat101. Medium confidence score level was 0.400. Data supporting proteinprotein interactions derived from experimental studies (dark purple lines), homology (light purple lines), databases (light blue lines), text mining (light green lines), concurrence (dark blue lines) and co-expression (black lines). Node colour is arbitrary

cells were transfected with pAcGFP1-Mito vector that encodes a green fluorescent protein (GFP) fused with a precursor of the cytochrome c oxidase VIII subunit in order to quantify the average amount of mitochondria. As mitochondrial pre-proteins are rapidly degraded in the cytoplasm by proteasomes when they are not properly imported into the mitochondria, GFP from pAcGFP1-Mito vector only occurs when the protein targets the mitochondria [41]. G-mean of green fluorescence intensity of the living cell population increased 


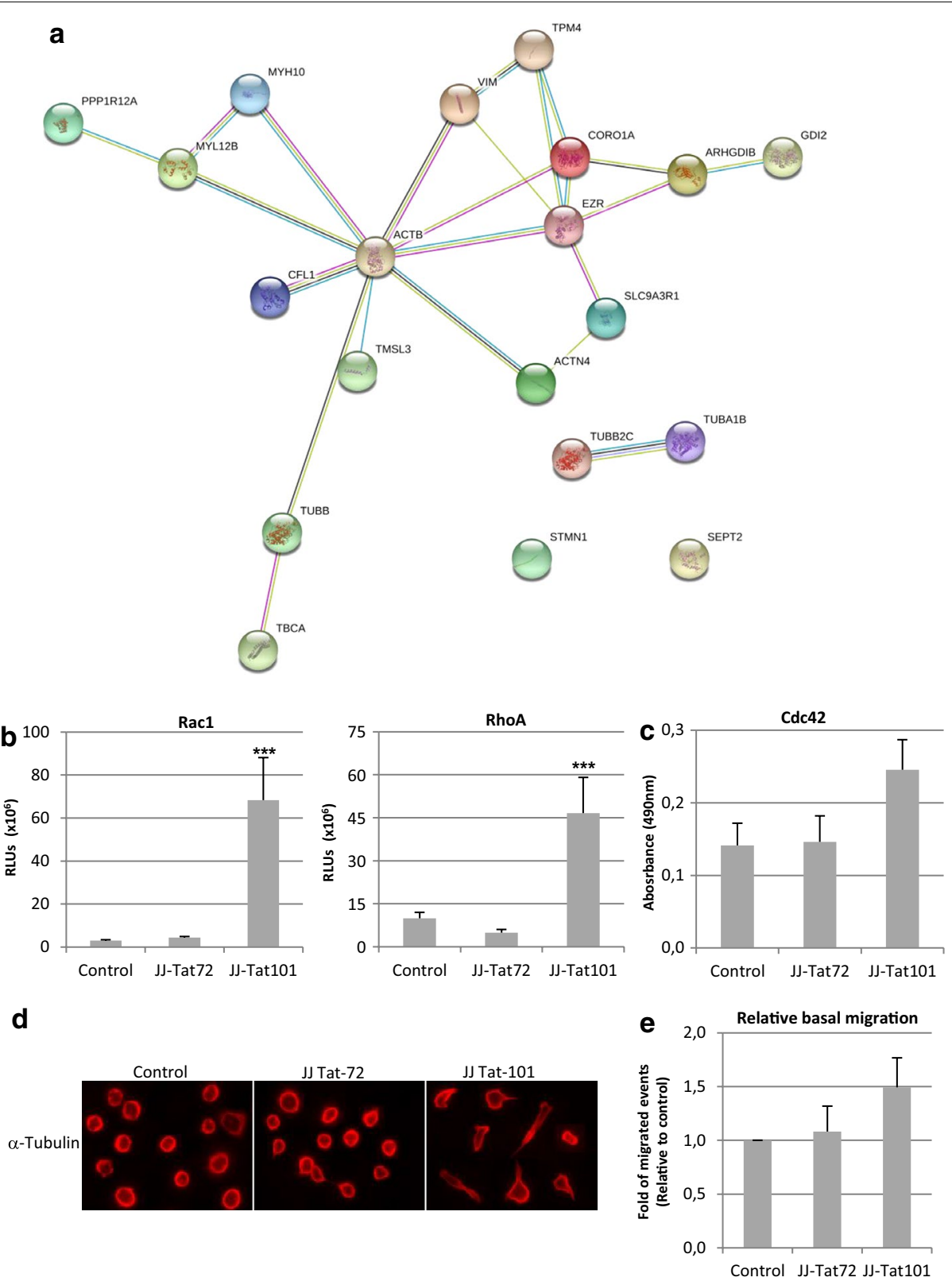

Fig. 7 Effect of intracellular Tat expression on cellular polarization and the expression of cytoskeleton-related proteins. a Network of predicted interactions between cytoskeletal network proteins deregulated in Jurkat-Tat101 vs control cells (as specified in Table 3). Medium confidence score level was chosen (0.400). Data supporting protein-protein interactions derived from experimental studies (dark purple lines), homology (light purple lines), databases (light blue lines), text mining (light green lines), concurrence (dark blue lines) and co-expression (black lines). Node colour is arbitrary. b Rac1 and RhoA GTPases activations were measured using a luminescence-based assay. Data shown are absolute RLUs from three independent experiments. c Cdc42 GTPase activation was measured in protein extracts using a colorimetric-based assay. Data shown are absolute absorbance at $490 \mathrm{~nm}$ from three independent experiments. d Cellular polarization was studied by immunofluorescence in Jurkat-Tat72, Jurkat-Tat 101 and control cells adhered to fibronectin using an antibody against $\alpha$-tubulin and a secondary antibody conjugated with Alexa-555. e Analysis of migration capacity in Jurkat-Tat72 and Jurkat-Tat101 in comparison with control cells in the absence of any migratory stimuli. The relative increase of migrated events in comparison with control cells from three independent experiments is shown. Statistical significance was calculated with Kruskal-Wallis test with Dunn's multiple comparison test $\left({ }^{* *} p<0.001\right.$ vs control)

5.17-fold in Jurkat-Tat101 cells but only 2.35 -fold in Jurkat-Tat72 cells, as compared to control cells $(p<0.005)$ (Fig. 8c). The levels of two mtDNA-segments that match with the area of COX-II and MTND-2 genes were measured by qPCR. The amount of mtDNA COX-II and MTND- 2 regions increased 1.7 -fold in Jurkat-Tat101 cells 
Table 3 Selection of proteins deregulated at least \pm 2.0 -fold in Jurkat-Tat 101 versus control cells

\begin{tabular}{|c|c|c|c|c|c|c|}
\hline Gene & Protein & $\begin{array}{l}\text { Tat72 vs } \\
\text { TetOff }\end{array}$ & $\begin{array}{l}\text { Tat101 vs } \\
\text { TetOff }\end{array}$ & Biological process & Peptide sequence & X-corr \\
\hline CORO1A & Coronin-1 A & 9.3 & 36.8 & Actin cytoskeleton organization & KLQATVQELQK & 2.93 \\
\hline MYL12B & $\begin{array}{l}\text { Myosin regulatory light } \\
\text { chain } 12 B\end{array}$ & 3.0 & 13.2 & Regulation of cell shape & $\begin{array}{l}\text { ELLTTMGDRFTDEEVDELYR } \\
\text { GNFNYIEFTR }\end{array}$ & $\begin{array}{l}1.75 \\
2.60\end{array}$ \\
\hline EZR & Ezrin & 11.2 & 11.9 & Actin filament bundle assembly & $\begin{array}{l}\text { QLLTLSSELSQAR } \\
\text { QLLTLSSELSQARDENKR }\end{array}$ & $\begin{array}{l}1.79 \\
2.06\end{array}$ \\
\hline SEPT2 & Septin-2 & 0.0 & 5.2 & Actin cytoskeleton organization & TMLITHMQDLQEVTQDLHYENFR & 2.29 \\
\hline CFL1 & Cofilin-1 & 0.9 & 5.2 & small GTPase signal transduction & LGGSAVISLEGKPL & 2.33 \\
\hline ACTN4 & Actinin-alpha-4 & 0.0 & 4.4 & Actin filament bundle assembly & $\begin{array}{l}\text { MAPYQGPDAVPGALDYK } \\
\text { GISQEQMQEFR }\end{array}$ & $\begin{array}{l}2.11 \\
2.11\end{array}$ \\
\hline TUBB2C & Tubulin beta-2C & 6.4 & 4.4 & Microtubule organization & INVYYNEATGGK & 1.75 \\
\hline SLC9A3R1 & $\begin{array}{l}\mathrm{Na} / \mathrm{H} \text { exchange regulatory } \\
\text { cofactor (NHE-RF1) }\end{array}$ & 3.1 & 3.5 & Actin cytoskeleton organization & $\begin{array}{l}\text { SVDPDSPAEASGLR } \\
\text { SVDPDSPAEASGLRAQDR }\end{array}$ & $\begin{array}{l}1.95 \\
1.33\end{array}$ \\
\hline PPP1R12A & $\begin{array}{l}\text { Protein phosphatase } 1 \\
\text { regulatory subunit } 12 \mathrm{~A}\end{array}$ & 5.2 & 2.8 & Actin cytoskeleton organization & NKETLIIEPEKNASR & 2.12 \\
\hline TPM4 & Tropomyosin alpha-4 chain & 9.9 & 2.2 & Actin cytoskeleton organization & KIQALQQQADEAEDR & $\begin{array}{l}1.65 \\
2.13\end{array}$ \\
\hline TBCA & $\begin{array}{l}\text { Tubulin-specific } \\
\text { chaperone A }\end{array}$ & 2.1 & 2.2 & Tubulin assembly & $\begin{array}{l}\text { LVLDSVKLEA } \\
\text { RLEAAYLDLQR }\end{array}$ & $\begin{array}{l}1.78 \\
1.84\end{array}$ \\
\hline VIM & Vimentin & 3.9 & 2.2 & Cytoskeleton organization & FADLSEAANR & 1.75 \\
\hline GDI2 & $\begin{array}{l}\text { Rab GDP dissociation } \\
\text { inhibitor beta }\end{array}$ & 0.0 & 2.0 & small GTPase signal transduction & MTGSEFDFEEMKR & 1.78 \\
\hline TUBA1B & Tubulin alpha-1B & 3.7 & -3.4 & $\begin{array}{l}\text { Microtubule cytoskeleton } \\
\text { organization }\end{array}$ & $\begin{array}{l}\text { TIGGGDDSFNTFFSETGAGK } \\
\text { DVNAAIATIK }\end{array}$ & $\begin{array}{l}1.91 \\
2.00\end{array}$ \\
\hline TUBB & Tubulin beta & -1.3 & -6.9 & $\begin{array}{l}\text { Microtubule cytoskeleton } \\
\text { organization }\end{array}$ & $\begin{array}{l}\text { FWEVISDEHGIDPTGTYHGDSDLQLDR } \\
\text { AILVDLEPGTMDSVR } \\
\text { EVDEQMLNVQNK } \\
\text { MSMKEVDEQMLNVQNK }\end{array}$ & $\begin{array}{l}2.16 \\
2.20 \\
2.74 \\
4.08\end{array}$ \\
\hline MYH10 & Myosin-10 & -2.3 & -8.5 & Actin filament-based movement & $\begin{array}{l}\text { ELDDATEANEGLSREVSTLKNR } \\
\text { QLEEAEEEATRANASR } \\
\text { ELDDATEANEGLSR }\end{array}$ & $\begin{array}{l}1.99 \\
2.38 \\
2.78\end{array}$ \\
\hline ARHGDIB & $\begin{array}{l}\text { Rho GDP-dissociation } \\
\text { inhibitor } 2\end{array}$ & -2.6 & -10.0 & small GTPase signal transduction & TLLGDGPVVTDPKAPNVWVTR & 1.97 \\
\hline STMN1 & Stathmin & -28.5 & -30.5 & Microtubule depolymerization & RAsGQAFELILsPR & 2.19 \\
\hline TMSL3 & $\begin{array}{l}\text { Thymosin beta-4-like } \\
\text { protein } 3\end{array}$ & -28.8 & -33.4 & Actin cytoskeleton organization & $\begin{array}{l}\text { NPLPSKETIEQEKQAGES } \\
\text { NPLPSKETIEQEK } \\
\text { TETQEKNPLPSKETIEQEK }\end{array}$ & $\begin{array}{l}1.80 \\
2.31 \\
2.65\end{array}$ \\
\hline ACTB & Actin cytoplasmic & -15.0 & -43.7 & Actin cytoskeleton organization & $\begin{array}{l}\text { DSYVGDEAQSK } \\
\text { DLYANTVLSGGTTMYPGIADR } \\
\text { DSYVGDEAQSKR } \\
\text { HQGVMVGMGQK } \\
\text { AVFPSIVGRPR } \\
\text { TTGIVMDSGDGVTHTVPIYEGYALPHAI } \\
\text { QEYDESGPSIVHR } \\
\text { HQGVMVGMGQKDSYVGDEAQSK } \\
\text { IWHHTFYNELR } \\
\text { MQKEITALAPSTMK }\end{array}$ & $\begin{array}{l}1.83 \\
1.87 \\
1.88 \\
1.89 \\
1.98 \\
2.15 \\
2.37 \\
2.81 \\
3.31 \\
3.52\end{array}$ \\
\hline
\end{tabular}

Only proteins related to actin and tubulin cytoskeleton networks were selected. All peptides selected showed $95 \%$ probability for protein expression and a minimum $\mathrm{X}$-corr of 1.75

$(p<0.005)$, while it only occurred in COX-II mtDNA fragment in Jurkat-Tat72 cells $(p<0.05)$ (Fig. $8 \mathrm{~d}$ ). This result confirms data from Fig. 2a showing enhanced mitochondria content in Jurkat-Tat cells.
PBLs expressing Tat-101 showed decreased synthesis of ATP and enhanced levels of lactate

PBLs are a more physiological cellular system than $T$ CD4+ Jurkat lymphocytes. Representative data were 


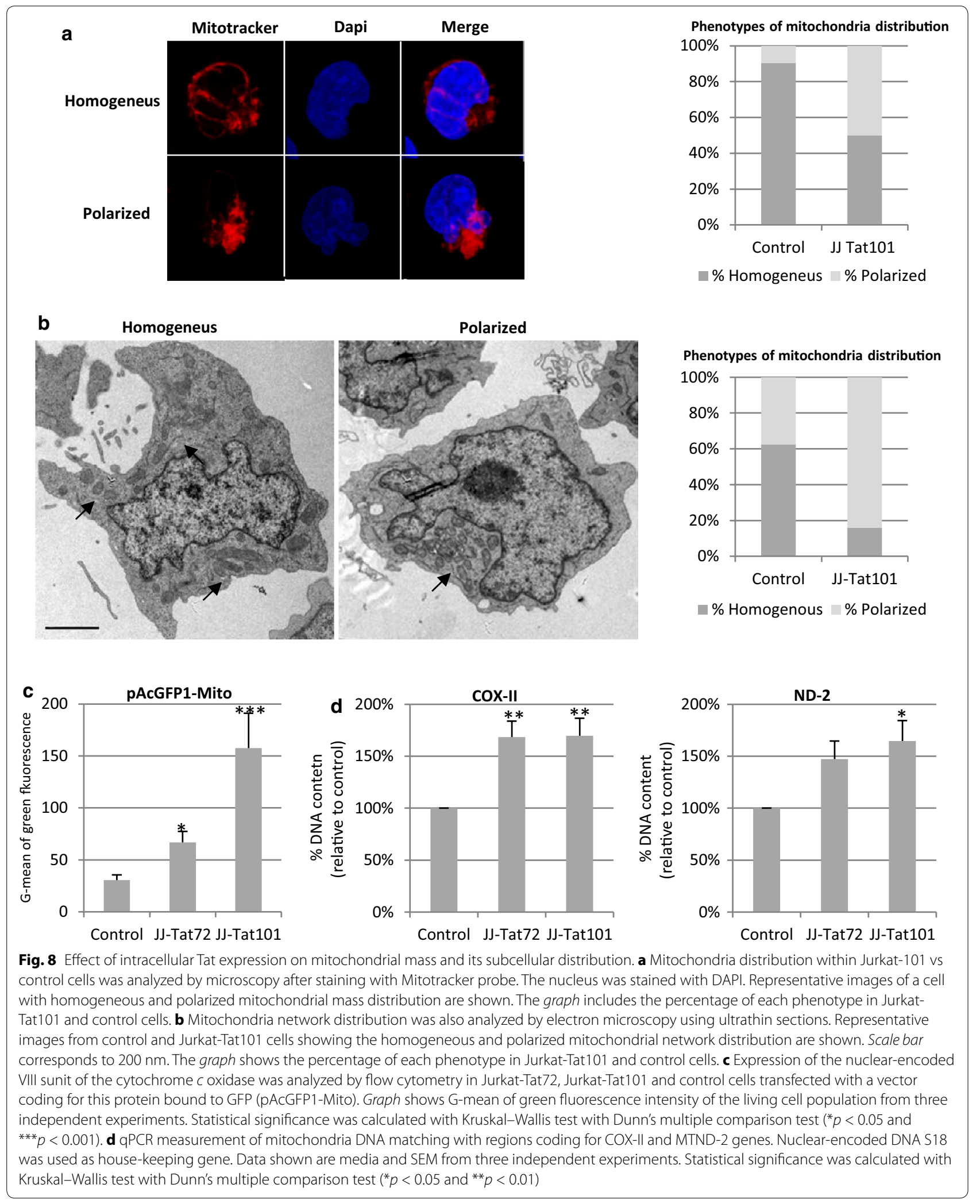


confirmed using peripheral blood lymphocytes (PBLs) from healthy donors that were transfected with a vector expressing Tat101 protein or with pcDNA3 as negative control. pEGFP vector was co-transfected to measure the transfection efficiency, which was $15 \%$ in all cases (Fig. 9a). Nuclear localization of intracellular Tat was confirmed by immunofluorescence. The intracellular levels of ATP were significantly 2.12-fold reduced in PBLs transiently expressing intracellular full-length Tat $(p<0.05)$ (Fig. 9b).

Relative data showing lactate concentrations in PBLs expressing Tat after normalization with lactate concentrations in control PBLs from the same donor are shown. In PBLs transiently expressing Tat101, intracellular and extracellular lactate levels increased 1.54- and 1.60fold $(p<0.05)$, respectively (Fig. 9c, d). Relative instead of absolute experimental data are shown because both intracellular and extracellular lactate concentrations varied among independent donors, but the same tendency was observed in each experiment. These results support our previous findings in Jurkat-Tat101 cells shown in Fig. 2.

\section{HIV-infected T lymphocytes shared some mitochondrial alterations with Tat expressing cells}

The importance of Tat in modifying mitochondrial main functions was evaluated in the context of viral replication. Jurkat cells were infected by electroporation with the Tat-defective viral genome pNL4.3-TatM1I [15] along with pTat101 or pcDNA3 as control vector. pEGFP vector was co-transfected to measure the transfection efficiency, which was 21 and $25 \%$ in control cells and in HIV-infected cells, respectively (Fig. 10a, upper panel). HIV-1 replication was assessed by quantifying p24/Gag levels in the culture supernatants (Fig. 10a, lower panel). The levels of p24/Gag increased 652.9-fold in transfected with NL4.3-TatM1I and expressing Tat101 versus control cells infected only with defective NL4.3-TatM1I. Control cells expressed similar levels of p24/Gag than cells transfected with pcDNA3 alone (data not shown). As HIV-1 replication occurred from vector expression, expression levels of Tat in pNL4.3-TatM1I transfected Jurkat cells were compared to Tat levels in Jurkat cells infected with HIV-1. Immunoblotting analysis showed that Tat expression levels were 2.0-fold increased in Jurkat cells transfected with pNL4.3-TatM1I along with pCMV-Tat101 vectors in comparison to Tat levels in Jurkat cells infected with NL4.3 virions (Additional file 1: Fig. S1a). Accordingly, HIV-1 replication, measured by quantifying p24/ Gag levels in the culture supernatant, was also 3.3-fold enhanced in transfected versus infected cells (Additional file 1: Fig. S1b). These data suggest that Tat expression from transfection or infection may be equivalent in
Jurkat cells. Neither Tat expression nor HIV-1 replication were found in non-infected Jurkat cells or in Jurkat cells transfected with pNL4.3-TatM1I along with pcDNA3 (Additional file 1: Fig. S1a, b).

The intracellular levels of ATP were 1.73-fold reduced in HIV-1 infected cells $(p<0.001)$ (Fig. 10b). The GSH/ GSSG ratio was significantly 2.22 -fold reduced $(p<0.05)$ (Fig. 10c) and caspase-3/7 activation was 1.52-fold enhanced $(p<0.05)$ (Fig. 10d) in HIV-1 infected cells.

Mitochondrial content was measured by quantifying the levels of two mtDNA-segments matching with COXII and MTND-2 genes and was 1.35-fold enhanced in HIV-infected cells $(p<0.05)$ (Fig. 10f). These data suggest that intracellular Tat101 is responsible for reduced ATP levels, caspase-3/7 activation and enhanced mitochondrial content during HIV-1 infection in T lymphocytes.

\section{Discussion}

Mitochondrial OXPHOS is altered in PBMCs from naïve patients [6, 7], demonstrating that HIV-1 replication per se results in mitochondrial damage independent of ART. In this work, we show that intracellular expression of Tat101 partly leads this process.

The expression of nuclear encoded genes involved in mitochondrial functions was upregulated in JurkatTat101 cells but the transcription of mtDNA genes was dramatically resulting in the impairment of mitochondria functions. This lack of coordination between mtDNA and nuclear genes expression may also result in a defective OXPHOS [42]. Accordingly, complex-I and complex$\mathrm{V}$ were inhibited in Jurkat-Tat101 cells. During HIV-1 infection, the inhibition of complex-I activity reduces the levels of ATP, although ATP synthesis does not stop completely [8]. Furthermore, the reduction of ATP activates a phosphofructokinase that finally increases the concentration of intracellular lactate [43]. Indeed, ATP levels were reduced and subsequently intracellular lactate was accumulated in the cytoplasm of PBLs transiently expressing Tat, CD4+ T cells expressing Tat101 and HIV-1 infected $\mathrm{T}$ cells. The modest effect of Tat observed in PBLs was probably due to lower transfection efficiency. It results in the dilution of Tat-mediated effects in the whole population of PBLs, as most of them were not expressing Tat intracellularly.

Lactate can trigger the degradation of Ік $\mathrm{B} \alpha$, resulting in the autocrine activation of the transcription factor NF- $\mathrm{BB}$ [44], which is essential for HIV-1 replication and gets activated upon intracellular Tat expression [14, $15,45]$. Intracellular lactate levels are secondly regulated by the use of the specific monocarboxylate transporter 1 (MCT1) that allows the diffusion of the lactate out of the cells [46]. Extracellular amounts of lactate did not significantly change in Jurkat-Tat cells, suggesting that high 

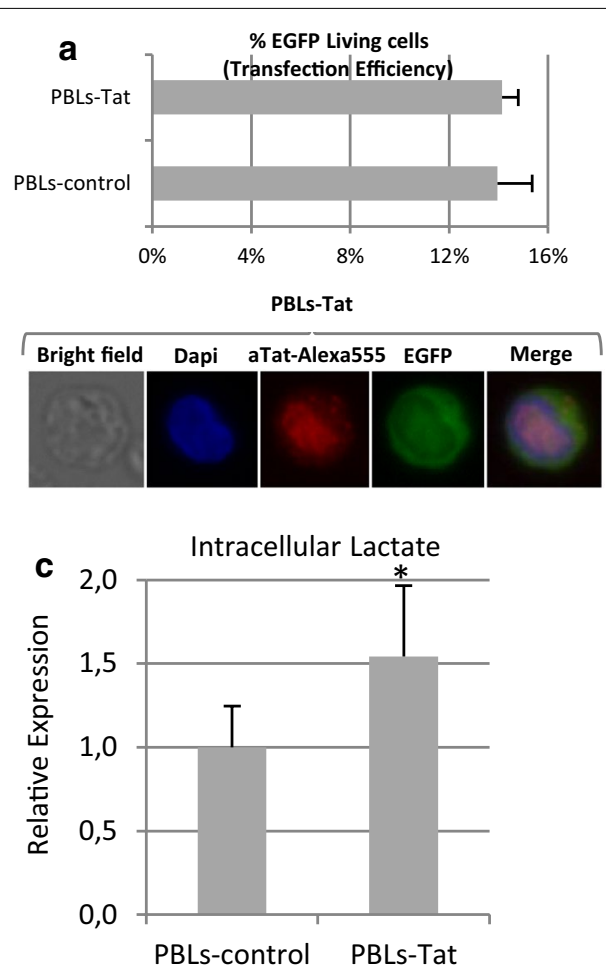
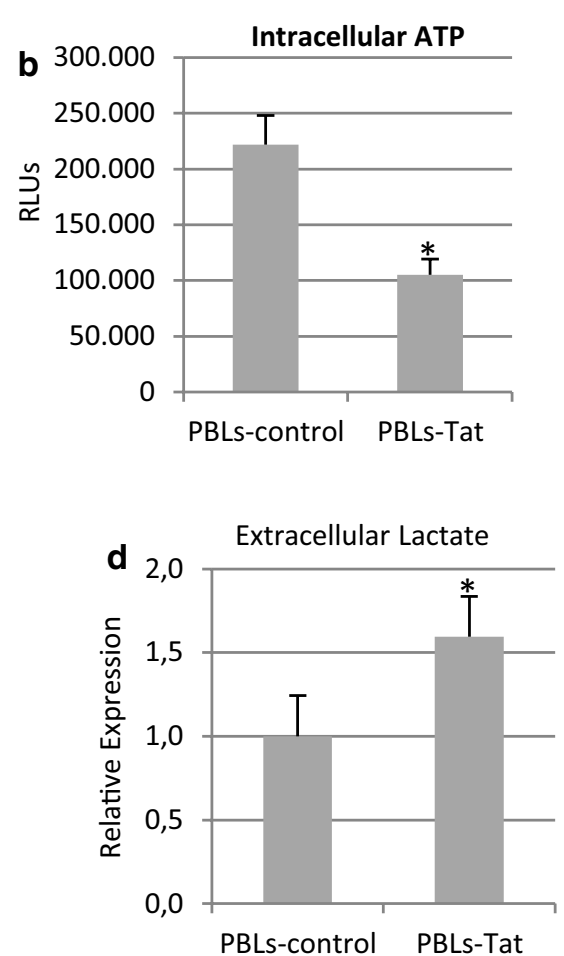

Fig. 9 Intracellular ATP production and intracellular lactate levels and release in PBLs expressing Tat101. Resting PBLs were transiently transfected with vectors CMV-Tat101 or pcDNA3, as negative control, along with pEGFP expression vector, as control of transfection efficiency. a Flow cytometry quantification of the percentage of living cells expressing EGFP was used to analyze transfection efficiency. Intracellular expression of Tat and nuclear subcellular localization were confirmed by immunofluorescence using a monoclonal antibody against Tat and a secondary antibody conjugated to Alexa 546. DAPI was used for nuclear staining. b ATP production was measured by chemiluminescence using a commercial assay. Data shown are RLUs mean and SEM of concentration from five independent experiments. $\mathbf{c}$ Relative intracellular lactate production measured in PBLs expressing Tat versus control PBLs. Data shown are relative mean and SEM of concentration from five independent experiments. $\mathbf{d}$ Relative release of lactate to the culture medium measured in the same PBLs expressing Tat used to measure intracellular lactate. Statistical significance was calculated by Mann-Whitney test $\left.{ }^{*} p<0.05\right)$

amounts of lactate can be supported without resulting in toxicity. However, enhanced lactate release was found in PBLs from healthy donors expressing Tat protein and in HIV-1 infected cells, reducing the possibility that Tat modifies the MCT1 during HIV-1 infection. Elevated lactate in blood is a noticeable toxic effect of ART and is used to define mitochondrial toxicity in treated HIV-1 patients [47].

Compensatory mechanisms for mitochondria toxicity, including mtDNA increase, have been shown in different subsets of human cells subjected to ART [47-49]. However, PBMCs from naïve patients show mtDNA depletion [6]. Here, we demonstrated that Tat101 increased the mitochondria content in $\mathrm{T}$ lymphocytes but not enough to compensate mitochondria impairment. Other discrepancies regarding mtDNA content have been described in adipose tissues from non-treated HIV-1 patients [50, 51], suggesting that the effect of HIV-1 on mitochondria may depend on connected factors that remain to be fully elucidated. Here, an increase of mitochondria content was described in HIV-1 infected cells, contrary to Jurkat-Tat101 cells. This finding suggests that during HIV-1 replication other viral proteins compensate Tat-mediated mitochondrial impairment, although not completely as ATP synthesis was also compromised in HIV-1 infected $\mathrm{T}$ cells.

In Jurkat-Tat101 cells, a compensatory mechanism may be changing the cellular preferred metabolism into aerobic glycolysis through a generalized up-regulation of glycolytic enzymes. Indeed, HIV-1 infected cells show a metabolic reprogramming that reduces the energy production from the tricarboxylic acid cycle to aerobic glycolysis [52, 53]. The aerobic glycolysis is a metabolic program, occurring usually in activated lymphocytes [25, 54], in which the lactate is produced in the presence of oxygen, to differentiate it from the anaerobic fermentation of glucose to lactate that arose from faults in respiration [24]. As it was discussed above, lactate production was enhanced in Jurkat-Tat101 cells, PBLs expressing Tat101 and HIV-1 infected cells. Furthermore, our data 


\section{a}
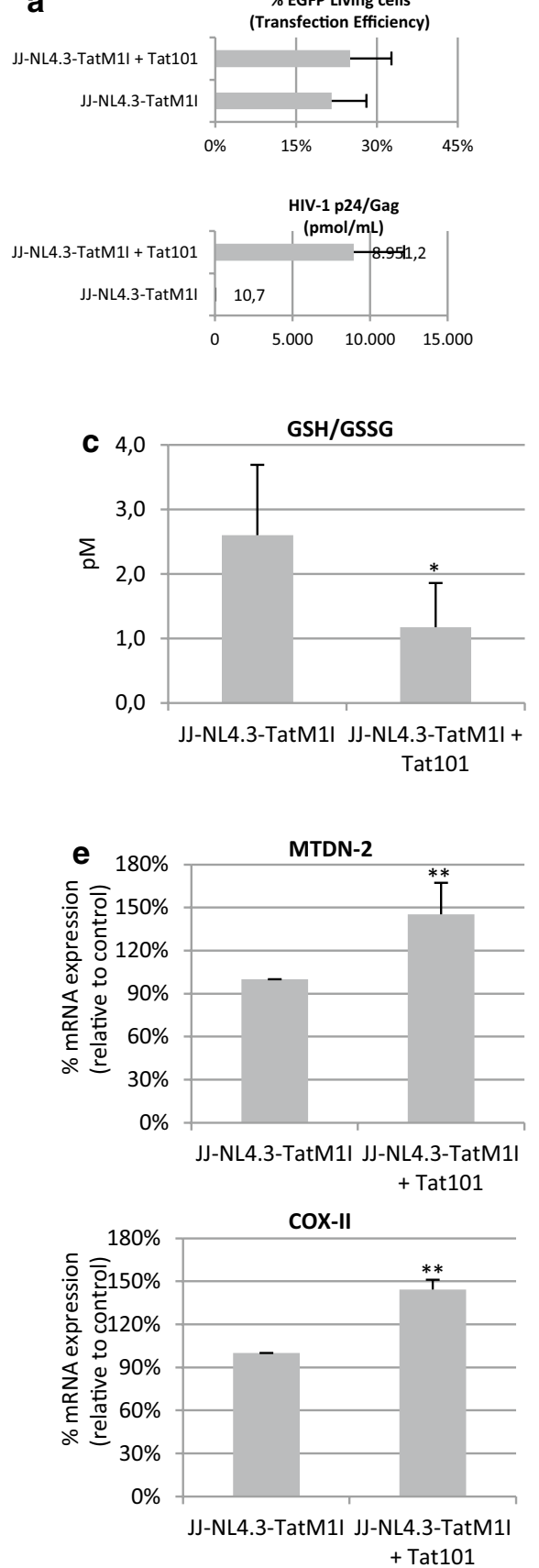
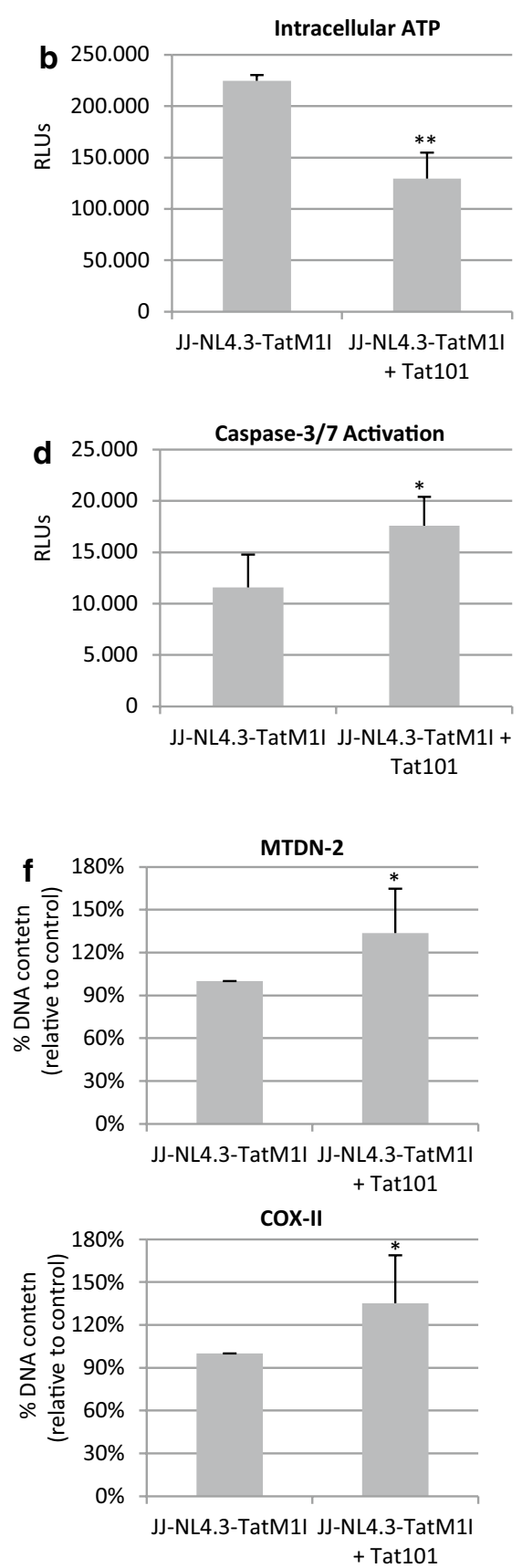

Fig. 10 Intracellular ATP levels, GSH/GSSG ratio, caspase-3/7 activation, mtDNA transcription and mitochondrial content in HIV-1 infected T lymphocytes. PBLs were infected pNL4.3-TatM1I vector along with pCDNA3 or with pCMV-Tat101 vector. pEGFP was co-transfetion as a control of transfection efficiency. a Flow cytometry quantification of the percentage of living cells expressing EGFP was used to analyze transfection efficiency (upper panel). Quantification of p24/Gag in culture supernatant was used as control of infection (lower panel). b Intracellular ATP production. c Intracellular concentration of GSH/GSSG. d Caspase-3/7 activation. Intracellular ATP, GSH/GSSG ratio and caspase-3/7 activation were measured by chemiluminescence using commercial assays. e qPCR analysis of mRNAs levels from the mtDNA-encoded genes MTND-2 and COX-II. mRNA levels of nucelar-encoded S18 expression were used as house-keeping gene. $\mathbf{f}$ qPCR analysis of mitochondria DNA matching with regions coding for COX-II and MTND-2 genes. Nuclear-encoded DNA S18 was used as house-keeping gene. Data shown are mean and SEM from three independent experiments. Statistical significance was calculated by Mann-Whitney test or Kolmogorov-Smirnov test $\left({ }^{*} p<0.05,{ }^{* *} p<0.01\right)$ 
suggest that the main breakdown point may include the synthesis of pyruvate and the intermediate metabolite glyceraldehyde 3-phosphate (G3P), probably through a dramatic repression of GAPDH. Additionally, intracellular Tat101 enhanced the expression of PKM2 and LDHB, which together increase the conversion of lactate from pyruvate in the cytoplasm. PKM2 is crucial for metabolism shift during HIV-1 pathogenesis, as up-regulation of PKM2 has been observed in different types of HIV-1 infected cells $[52,55,56]$. In contrast to OXPHOS, glycolysis is energetically inefficient, theoretically yielding two molecules of ATP per glucose molecule consumed compared to thirty-six if it is fully oxidized. However, aerobic glycolysis has the energetic advantage of generating ATP at higher speed than OXPHOS [57]. Therefore, activated lymphocytes do not activate aerobic glycolysis only because their capacity for OXPHOS is saturated but also to provide sufficient ATP to support the cellular growth and proliferation [58-60]. In summary, aerobic glycolysis may be activated in Jurkat-Tat101 cells as a complementary source of ATP production.

Increased production of ROS due to diminished complex I activity and subsequent reduction in ATP levels has been extensively described in infected CD4+ T cells [8]. Indeed, extracellular Tat is known to increased generation of ROS and caspase-3/7 activation in the intestinal mucosa of HIV-infected patients [20]. In this work, it is shown that intracellular Tat101 increased ROS production and apoptosis induction, and both processes were coupled. However the GSH/GSSG ratio was balanced in Jurkat-Tat101 cells despite of the chronic oxidative stress detected in HIV-1 infected lymphocytes. Therefore, our data cannot point out a role of intracellular Tat expression in the overall glutathione imbalanced showed in PBLs from HIV-1 infected patients. Because of the experimental systems used in this work, we cannot rule out the role of other viral proteins in the induction of oxidative stress and mitochondrial damage in infected $\mathrm{T}$ cells. In particular, extracellular Tat and other viral proteins as extracellular Vpr are able to reduce GSH/GSSG ratio [20,61], and may gain value during HIV-1 infection in vivo. Although chronic oxidative stress is detected in HIV patients [62, 63], most in vivo studies are focused on patients under ART, where viral load is not detectable [64-67] and treatment enhances the synergy of HIV and oxidative stress [68]. This fact together with the low number of productively infected lymphocytes in peripheral blood HIV-1 in vivo infection $[69,70]$ suggest that not only HIV-1 replication itself but additional factors may contribute to oxidative stress as part of HIV-1 disease pathogenesis. This phenomenon may be related to the chronic immune activation and senescence produced by increased microbial translocation and persistent viremia or secondary to the increased rate of opportunistic infections as it has been described [71-73].

ROS levels are responsible for the profound reorganization of mitochondria-cytoskeletal interactions found in HIV-1 patients [7]. Furthermore, ROS lead to the appearance of dense stress fibers, required for intercellular contacts and migration [74]. In line with it, the mitochondria network of Jurkat-Tat101 cells was localized at one edge of the lymphocyte, reflecting the acquisition of a polarized shaped and probably as a host defense response to supply enough energy to the migration process. Because mitochondria are transported to the uropod along microtubules [38], it seems that microtubule dynamics are persevered in Jurkat-Tat cells for mitochondria trafficking and delocalization at the uropod. Furthermore, profound actin cytoskeleton changes may also be responsible for Tat-mediated mitochondria delocalization. For instance, intracellular Tat101 activated RhoA and Rac1, actin remodeling GTPases that control mitochondria trafficking [75], probably through the depletion of ARHGDIB, a protein that promotes the misfolding and degradation of the cytosolic pool of Rho GTPases together with the activation of the remaining membrane bound pool $[76,77]$. Accordingly, mitochondria proteome from HIV-infected patients are enriched in actin proteins [7], including the GTPase Rab1, which regulates organelle tethering through the enhancement of Rab GDP dissociation inhibitor beta protein (GDI2) [78], a modulator of Rab recycling that is up-regulated in Jurkat-Tat cells. Eventually, mitochondria accumulation also requires an unperturbed balance between fusion and fission processes [38], which might occur in Jurkat-Tat101 cells as the expression of pro-fusion MFN2 and pro-fission DNM1L genes were not deregulated.

It is to notice that Tat is indispensable for HIV-1 replication $[13,79,80]$ and it is not packaged inside the virions [81]. Accordingly, NL4.3-TatM1I strain lacking Tat protein did not yield productive infection. Therefore only the transfection approach based on co-expressing NL4.3TatM1I strain and Tat101 allowed a proper assessment of the impact of Tat on the different mitochondrial parameters during HIV-1 replication. Therefore, results from Jurkat expressing only intracellular Tat do not always correlate with data from infection, where other viral proteins exert compensatory mechanisms to success viral replication.

\section{Conclusions}

This work shows the influence of intracellular HIV-1 Tat protein on mitochondrial overall functions in Jurkat cells and PBLs. Tat101 polarized the mitochondria distribution and increased the mitochondrial content, probably to compensate mtDNA transcription impairment and 
low ATP production. Tat101 also enhanced the expression of metabolism-related proteins and mitochondrialrelated genes. The presence of Tat second exon increased these effects, confirming that full-length Tat mostly regulated the non-transcriptional functions of the protein. The intracellular expression of Tat may be responsible for the mitochondrial dysfunctions found in HIV-1 infected patients as for instance OXPHOS impairment and increased mtDNA content and therefore Tat may enhance the susceptibility to mitochondrial toxicity during ART.

\section{Methods \\ Cells}

Jurkat TetOff cell line was purchased from BD Biosciences Clontech (Mountain View, CA, USA). The highlevel gene expression TetOff system [82], which keeps the expression of the gene cloned in pTRE2hyg vector continually turned on. Unlike other inducible mammalian expression systems, gene regulation in the Tet systems is highly specific, so the interpretation of results would not be hindered by pleiotropic effects or nonspecific induction (Yin et al. 1996). The vector pTRE2hygTat101 expressed a complete HIV-1 tat gene (aa 1-101), obtained from pCMV-Tat101 vector [83], after cloning in pTRE2hyg vector (Clontech, BD Tet-Off gene expression System, BD Biosciences). Complementary DNA (cDNA) from tat first exon (1-219nt; 1-72aa) was obtained from pCMV-Tat101 vector using specific oligonucleotides to introduce a stop codon at residue 73 , and then cloned in pTRE2hyg vector. Jurkat TetOff was transfected by electroporation with pTRE2hyg-Tat72 or pTRE2hyg-Tat101 vectors and these cell lines were stabilized with hygromycin B as previously described [14, 16]. The empty pTRE2hyg vector was transfected and stabilized in the Jurkat TetOff cell line into obtained negative control cells. Jurkat-Tat101 and Jurkat-Tat72 cells are not clone populations but a mixed population in which more than $75 \%$ of the cells express high intracellular amounts of Tat101 (full-length) or Tat72 (first exon) protein which were equivalent to Tat levels detected in T lymphocytes infected with the HIV-1 infectious clone NL4.3wt [16]. All Jurkat cells were cultured in RPMI 1640 medium (Biowhittaker, Walkersville, MD, USA) with $10 \%$ fetal calf serum (PAN Biotech GmbH, Aidenbach, Germany), $2 \mathrm{mM}$ L-glutamine, $100 \mu \mathrm{g} / \mathrm{ml}$ streptomycin and 100 $\mathrm{U} / \mathrm{ml}$ penicillin (Lonza, Basel, Switzerland), $300 \mu \mathrm{g} / \mathrm{ml}$ geneticin and $300 \mu \mathrm{g} / \mathrm{ml}$ hygromycin B (BD Biosciences Clontech), at $37{ }^{\circ} \mathrm{C}$ and $5 \% \mathrm{CO}_{2}$. Serum depletion was performed $3 \mathrm{~h}$ before each experiment. PBLs were isolated from blood of healthy donors by centrifugation through a Ficoll-Hypaque gradient (Pharmacia Corporation, North Peapack, NJ, USA) and cultured in RPMI
1640 medium supplemented with $10 \%(\mathrm{v} / \mathrm{v})$ fetal calf serum (FCS), $2 \mathrm{mM}$ L-glutamine, $100 \mu \mathrm{g} / \mathrm{ml}$ streptomycin, $100 \mathrm{U} / \mathrm{ml}$ penicillin (Biowhittaker, Walkersville, MD, USA).

\section{Antibodies, reagents and vectors}

Anti-tubulin, MitoTracker CMxRos probe $(0.2 \mu \mathrm{M})$ and 4',6-diamidino-2-phenylindole (DAPI) were purchase from Sigma-Aldrich. Antibody against HIV-1 Tat was obtained from Advanced Biotechnologies Inc. (Columbia, MD, USA). pCMV-Tat101 vector expresses HIV-1 Tat101 protein [84]. pAcGFP1-Mito vector (BD Biosciences, Erembodegem, Belgium) encodes the GFP derived from Aequorea coerulescens fused at its N-terminus with a precursor of the cytochrome c oxidase VIII subunit [41].

\section{Proteome analysis and criteria for protein identification}

Proteome analysis was performed as previously described [15]. Briefly, $200 \mu \mathrm{g}$ of trypsin-digested proteins were loaded into the LC-MS/MS system and analyzed using a $\mathrm{C}-18$ reversed phase nano-column (Thermo-Fisher, San Jose, CA, USA). Real-time ionization and peptide fragmentation was performed on an orbital ion trap mass spectrometer (LTQ Orbitrap XL, Thermo Fisher Scientific, San Jose, CA, USA) [85]. For peptide database searching, tandem mass spectra were analysed using Sequest (Thermo Fisher Scientific; version 1.3.0.339) and X! Tandem (http://www.thegpm.org; version CYCLONE). Sequest and X! Tandem were searched with a fragment ion mass tolerance of 30 PPM and a parent ion tolerance of 15 PPM. Scaffold 3.0 (Proteome Software Inc., Portland, OR, USA) was used to validate peptide identifications. Only peptide established at a probability greater than $95 \%$ and with XCorr-score values above 1.75 were accepted. Proteins related to mitochondria and cytoskeleton that changed at least \pm 2.0 -fold in Jurkat-Tat101 were selected and subjected to analysis with STRING 9.0 database (http://string-db.org/) [86].

\section{PCR and RT-PCR assays}

DNA and total RNA was isolated with QiAmp DNA blood mini kit and RNeasy Mini kit (Qiagen, Barcelona, Spain), respectively. cDNA was synthesized using GoScript Reverse Transcription System (Promega, WI, USA). Specific primers are described in Additional file 2: Table S1. The expressions Ribosomal protein S18 (S18) was used as housekeeping gene. The PCR amplification was performed in a StepOnePlus ${ }^{\mathrm{TM}}$ Real-Time PCR Systems (Applied Biosystems, CA) using SYBR Green. Data analysis was performed with 7500 software v2.0.6 and Ct values were normalized according to S18 amplification and analyzed with the formula $2^{-\Delta \Delta C t}$. 


\section{Expression of nuclear-encoded genes related to mitochondria}

$\mathrm{RT}^{2}$ Profiler $^{\mathrm{TM}}$ PCR Array Human Mitochondria (Qiagen) is a RT-PCR based array and was used to studied the expression of 84 mitochondrial related genes which are nuclear encoded. The array also included five housekeeping genes and internal controls for genomic DNA amplification, reverse transcription and positive PCR controls. Genomic RNA elimination and reserve transcription was performed using $5 \mu \mathrm{g}$ of total RNA of Jurkat-control and Jurkat-Tat101 cells, following manufacturers' instructions. The PCR amplification was performed in a StepOnePlus ${ }^{\mathrm{TM}}$ Real-Time PCR Systems (Applied Biosystems) using SYBR Green. Data analysis was performed accordingly to the instructions detailed in $\mathrm{RT}^{2}$ Profiler $^{\mathrm{TM}}$ PCR Array Human Analysis Manual. $C_{\mathrm{T}}$ higher than 30 cycles were rejected for further analysis. $C_{T}$ values were normalized according to the amplification of five housekeeping genes included in the array amplification and analyzed with the formula $2^{-\Delta \Delta C t}$.

Activity of citrate synthase and OXPHOS complexes I and V The enzymatic activity of citrate synthase (EC 2.3.3.1) was measured with Citrate Synthase Assay Kit (SigmaAldrich). Briefly, $1 \times 10^{7}$ cells were lysed with $125 \mu \mathrm{l}$ of Cellytic M cell Lysis Reagent and $10 \mu \mathrm{l}$ of this lysate was incubated with $200 \mu \mathrm{l}$ of a reaction mix containing acetylcoA, DTNB and oxaloacetic acid. Changes in the absorbance at $412 \mathrm{~nm}$ were followed in a microplate reader Sunrise (Tecan Group Ltd., Männedorf, Switzerland) to calculate the units $(\mu \mathrm{mole} / \mathrm{ml} / \mathrm{min})$ of citrate synthase accordingly to the manufacturer's instructions. The activities of complex I (NADH dehydrogenase or ubiquinone oxidoreductase, EC 1.6.5.3) and complex V (F1F0 ATPase or ATP synthase, EC 3.6.3.14) were measured using complex I Enzyme Activity Microplate Assay Kit (Abcam) and ATP synthase (complex V) Human Profiling ELISA Kit (Abcam), respectively, according to manufacturer's instructions. Complex I assay is based on the oxidation of nicotinamide adenine dinucleotide (NADH) to NAD+ and the simultaneous reduction of a dye leading to an increase of absorbance at $450 \mathrm{~nm}$, which was measured in a microplate reader Sunrise. Briefly, protein from $6 \times 10^{6}$ cells were extracted by diluting $1 / 10$ the extraction buffer. A total of $200 \mu \mathrm{g}$ of protein from supernatants in $50 \mu \mathrm{l}$ of final volume was added in each well and incubated for $3 \mathrm{~h}$ at room temperature before accurate washing and adding $200 \mu \mathrm{l}$ of assay solution, containing $40 \mathrm{mM} \mathrm{NADH}$. The absorbance was measured at $450 \mathrm{~nm}$ at approximately 30 s's intervals for $30 \mathrm{~min}$. To quantify complex-V activity, a total of $200 \mu \mathrm{g}$ of protein extracted $6 \times 10^{6}$ cells was added in each well which is coated with a capture antibody specific for human ATP synthase. After $2 \mathrm{~h}$ incubation at room temperature and continuous shaking at $300 \mathrm{rpm}$, wells were washed and further incubated with an anti- ATP synthase detector antibody and then with a specific HRP-conjugated antibody. The TMB substrate solution and hydrochloric acid used as stopping solution were added to each well and the color intensity was measured at $450 \mathrm{~nm}$ using a microplate reader Sunrise. To assess OXPHOS complex I and complex V activities, absorbance values were normalized accordingly to mitochondria content using citrate synthase levels.

\section{ATP and lactate concentrations}

Intracellular levels of ATP were determined with CellTiter-Glo ${ }^{\circledR} 9$ Luminescent Cell Viability Assay (Promega), following the manufacturer's instructions. Briefly, $1 \times 10^{5}$ cells were incubated for $10 \mathrm{~min}$ at room temperature in CellTiter-Glo ${ }^{\circledR}$ Reagent, which contained lysis buffer and thermostable luciferase and the luminescent signal was analyzed in an Orion Microplate Luminometer with Simplicity software (Berthold Detection Systems, Oak Ridge, TN, USA). Intracellular and extracellular levels of $\mathrm{L}_{-}(+)-$ Lactate were measured in cell lysates or supernatants using Lactate Assay Kit II (Sigma-Aldrich) accordingly to manufacturer's instructions. Briefly, $1 \times 10^{6}$ cells were lysed with 4 volumes of lysis buffer or pelleted to collect the subsequent supernatant and $50 \mu \mathrm{l}$ of each sample was incubated with the commercial enzyme during $30 \mathrm{~min}$ at room temperature. The absorbance at $450 \mathrm{~nm}$, which was proportional to the lactate concentration, was determined using in a microplate reader Sunrise.

\section{Intracellular ROS and glutathione levels}

Living Jurkat-Tat cells were adhered onto fibronectincoated plates and stained with DCF-DA $2^{\prime}, 7^{\prime}-(5 \mu \mathrm{M})$ (Sigma-Aldrich), which after oxidation is converted into highly fluorescent DCF (2/7'-dichlorofluorescein) [26]. Images were obtained with a Leica DMI 4000B Inverted Microscope (Leica Microsistemas, Barcelona, Spain). Cells from a total of 15 fields from three independent experiments were analyzed. Fluorescence from cells stained with DCF-DA-FITC was also measured by FACScalibur Flow Cytometer (BD Biosciences Clontech) using FL-1 channel and data were analysed by CellQuest software. Intracellular levels of reduced glutathione (GSH) and oxidized glutathione (GSSG) were measured using the luminescence-based GSH/GSSG-Glo Assay (Promega). The luminescent signal (relative light units, RLUs) was quantified in an Orion Microplate Luminometer with Simplicity software and RLUs were converted into concentration ( $\mathrm{pM}$ ) using the glutathione standard curve included in the assay. 


\section{Apoptosis assays}

Living cells were adhered on PolyPrep slides, fixed with $2 \%$-PFA and treated with Dapi (4',6-diamidino2-phenylindole) (Sigma-Aldrich) for staining the nuclei. Images were obtained with a Leica DMI 4000B Inverted Microscope (Leica Microsistemas, Barcelona, Spain). The percentage of apoptotic events was calculated by acquiring 60 fields from three independent experiments-containing an average number of cells close to 40 - and considering the total number of cells. Activation of casapse- 3 was measured in non-treated cells with CaspaseGlo ${ }^{\circledR} 3 / 7$ systems (Promega). The luminescent signal (relative light units, RLUs), which was directly proportional to caspase activation, was quantified in an Orion Microplate Luminometer with Simplicity software (Berthold Detection Systems). Cells were stained with Annexin-V-PE (Immunostep, Salamanca, Spain) to measure apoptosis commitment. Cells were co-stained together with DCF-DAC and Annexin-V-PE to measure the co-localization of apoptosis and ROS production. Fluorescence was measured by FACScalibur Flow Cytometer (BD Biosciences Clontech) and data were analyzed by CellQuest software.

\section{Immunofluorescence and electron microscopy assays}

Living cells were stained with MitoTracker Red CMxRos Mitochondrial $(0.2 \mu \mathrm{M})$ and then adhered on PolyPrep slides (Sigma-Aldrich) and fixed with $2 \%$ paraformaldehyde (PFA) in PBS1x. To study cellular polarization, cells were adhered on fibronectin-coated slides, fixed with $2 \%$-PFA and stained with anti-tubulin by immunofluorescence assay previously described [14]. Nuclei were stained using 4',6-diamidino-2-phenylindole (Dapi) from Sigma-Aldrich. Cells from a total of 15 fields from three independent experiments were analyzed. Images were obtained with a Leica DMI 4000B Inverted Microscope (Leica Microsistemas, Barcelona, Spain). For electron microscopy ultrastructural analysis, cells were fixed with a mixture of $2 \%$ glutaraldehyde and $4 \%$ PFA $0.1 \mathrm{M}$ phosphate buffer ( $\mathrm{pH} 7.4$ ) for $2 \mathrm{~h}$ at $4{ }^{\circ} \mathrm{C}$, washed three times in phosphate buffer; and postfixation was performed with a $1 \%$ osmium tetroxide and $1 \%$ potassium ferricyanide and $0.15 \%$ tannic acid. Samples were treated with $2 \%$ uranyl acetate and dehydrated in increasing concentrations of ethanol (50, 75, 90, 95, and $100 \%$ ). Finally, infiltration in epoxy-resin was done using increasing concentrations of resin $(25,50,75$ and $100 \%)$ and polymerization was performed at $60{ }^{\circ} \mathrm{C}$. Ultrathin sections of the samples were stained with saturated uranyl acetate and $2 \%$ lead citrate following standard procedures and sections were imaged with a Tecnai 12 FEI microscope (FEI, Hillsboro, Oregon, USA) operated at $120 \mathrm{kV}$.

\section{Activation of small GTPases and cellular migration}

Rac1 and RhoA GTPase activation was measured using G-LISATM Rac1 activation Assay Biochem $\mathrm{Kit}^{\mathrm{TM}}$ and G-LISA $^{\text {TM }}$ RhoA activation Assay Biochem KitTM (Cystoskeleton, Denver, CO, USA), which are luminescence based. Cdc42 GTPase activation was measured with the colorimetric assay G-LISATM Rac1 activation Assay Biochem $\mathrm{Kit}^{\mathrm{TM}}$ (Cystoskeleton). Migration of living cells was allowed for $2 \mathrm{~h}$ at $37^{\circ} \mathrm{C}$ with $5 \% \mathrm{CO}_{2}$ in transwell plates with $5 \mu \mathrm{m}$-pore filters (Costar, Cambridge, MA, USA) and quantified by flow cytometry.

\section{HIV-1 infection}

Jurkat cells were in vitro infected by electroporation. pNL4.3-TatM1I vector was co-transfected along with pCMV-Tat101 in a proportion 2:1 as previously described [15]. pNL4.3-TatM1I vector is similar to PNL4.3 wildtype but contains a point mutation in the start codon of the tat gene, and therefore it is not able to infect productively [15]. pCMV-Tat101 vector expresses HIV-1 Tat101 wild type protein [84]. pNL4.3-TatM1I vector co-transfected with pcDNA3 vector was used as negative control. pEGFP vector (BD Biosciences Clontech) was used as control of transfection efficiency. The production of infectious HIV-1 progeny was confirmed by quantifying the levels of p24/Gag in the culture supernatant $48 \mathrm{~h}$ post-transfection.

\section{Quantification of Tat levels in HIV-1 infected cells}

Briefly, infectious supernatants were obtained from calcium phosphate transfection of HEK293T cells with pNL4.3-wt plasmid. Jurkat cells were infected with $10 \mathrm{ng}$ of p24/Gag equivalent of NL4.3 strain per million cell by spinoculation during $30 \mathrm{~min}$ at gently rotation and room temperature. Non-infected Jurkat cells were used as negative control. Jurkat cells were also infected by electroporation. pNL4.3-TatM1I vector was co-transfected along with pCMV-Tat101 or with pcDNA3 vector as negative control. pEGFP vector was used as control of transfection efficiency. Whole protein extracts were obtained 5 days post-infection and 100 ug were fractionated by sodium dodecyl sulfate-polyacrilamide gel electrophoresis (SDS-PAGE). Expression levels of Tat were analyzed by immunobloting analysis (western-blot) using mouse monoclonal antibody to HIV-1 Tat regulatory protein (aa 1-16) (Biotechnologies, ABI, Columbia). Images were acquired in a BioRad Geldoc 2000 and densitometry was performed with Quantity One software (BioRad Laboratories, Madrid, Spain) with Quantity One software. The relative ratio of the optical density units corresponding to each sample was calculated regarding the internal control of each lane after subtracting background noise. 


\section{Statistical analysis}

Statistical analysis was performed using Graph Pad Prism 5.0 (San Diego, CA, USA). Comparisons among control, Jurkat-Tat72 and Jurkat-Tat101 cells were made using nonparametric Kruskal-Wallis test with Dunn's Multiple Comparison post hoc analysis. Non-parametric Mann-Whitney test was used to compare PBLs expressing or not Tat101 and HIV-1 infected cells versus control. Non-parametric Kolmogorov-Smirnov test was used to compared DNA and RNA PCRs data in HIV-1 infected cells versus control, as normalized data yielded the same value in control cells. The $p$ values $(p)<0.05$ were considered statistically significant.

\section{Additional files}

Additional file 1: Figure S1. Tat levels during HIV-1 infection in T cells. Additional file 2: Table S1. List of oligonucleotides designed for mtDNA amplification.

\section{Authors' contributions}

SRM carried out the experiments describing activity of citrate synthase, activation of respiratory complexes, quantification of ATP and lactate concentrations; developed experiments of HIV-1 infected cells and qRT-PCR for mitochondrial genes. EM provided technical assistance. MM and MAM, gave scientist advice regarding mitochondria functions and statistical analysis. JAL and EC developed mass spectrometry acquisition data. MCT and DL designed acquisition of electron-microscopy images. DM supported cytoskeletal experiments. JA and MC, conceived and funded the study; helped to drafted the manuscript. MRLH, conceived the study and interpreted the results; carried out experiments quantifying ROS and glutathione levels, qRT-PCR for mitochondria content and mtDNA transcription and proteome data analysis; wrote the manuscript. All authors read and approved the final manuscript.

\begin{abstract}
Author details
${ }^{1}$ Unidad de Inmunopatología del SIDA, Centro Nacional de Microbiología, Instituto de Salud Carlos III, Majadahonda, Madrid, Spain. ${ }^{2}$ Laboratorio de Enfermedades Raras: mitocondriales y neuromusculares, Instituto de Investigación Hospital 12 de Octubre, "i + 12", Madrid, Spain. ${ }^{3}$ Centro de Investigación Biomédica en Red de Enfermedades Raras (CIBERER) U723, Madrid, Spain. ${ }^{4}$ Unidad de Proteómica, Centro Nacional de Investigaciones Cardiovasculares, Madrid, Spain. ${ }^{5}$ Unidad de Microscopía Electrónica y Confocal, Centro Nacional de Microbiología, Instituto de Salud Carlos III, Majadahonda, Madrid, Spain. ${ }^{6}$ Unité de Virologie Humaine - INSERM U758/École Normale Supérieure, Lyon, France. ${ }^{7}$ Present Address: Laboratoire de Domaines Membranaires et Assemblage Viral, Centre d'études d'agents Pathogènes et Biotechnologies pour la Santé, Montpellier, France.
\end{abstract}

\section{Acknowledgements}

We greatly appreciate the secretarial assistance of Mrs Olga Palao. This work was supported by FIPSE (360924/10), Spanish Ministry of Economy and Competitiveness (SAF2010-18388), Spanish Ministry of Health (EC11285), AIDS Network ISCIII-RETIC (RD12/0017/0015), Instituto de Salud Carlos III, Spanish Ministry of Economy and Competitiveness (FIS PI12/00506). The work of Sara Rodríguez-Mora is supported by a fellowship of Sara Borrell from Spanish Ministry of Economy and Competitiveness (2013). The work of María Rosa López-Huertas is supported by a fellowship of the European Union Programme Health 2009 (CHAARM).

\section{Compliance with ethical guidelines}

\section{Competing interests}

The authors declare that they have no competing interests.
Received: 26 November 2014 Accepted: 26 August 2015

Published online: 16 September 2015

\section{References}

1. Stevenson M. HIV-1 pathogenesis. Nat Med. 2003;9:853-60.

2. Appay $V$, Almeida JR, Sauce D, Autran B, Papagno L. Accelerated immune senescence and HIV-1 infection. Exp Gerontol. 2007;42:432-7.

3. Bohr VA, Stevnsner T, De Souza-Pinto NC. Mitochondrial DNA repair of oxidative damage in mammalian cells. Gene. 2002;286:127-34.

4. Trifunovic A, Wredenberg A, Falkenberg M, Spelbrink JN, Rovio AT, Bruder $C E$, et al. Premature ageing in mice expressing defective mitochondrial DNA polymerase. Nature. 2004;429:417-23.

5. Macho A, Castedo M, Marchetti P, Aguilar JJ, Decaudin D, Zamzami N, et al. Mitochondrial dysfunctions in circulating T lymphocytes from human immunodeficiency virus-1 carriers. Blood. 1995;86:2481-7.

6. Miro O, Lopez S, Martinez E, Pedrol E, Milinkovic A, Deig E, et al. Mitochondrial effects of HIV infection on the peripheral blood mononuclear cells of HIV-infected patients who were never treated with antiretrovirals. Clin Infect Dis. 2004;39:710-6.

7. Ciccosanti F, Corazzari M, Soldani F, Matarrese P, Pagliarini V, ladevaia V, et al. Proteomic analysis identifies prohibitin down-regulation as a crucial event in the mitochondrial damage observed in HIV-infected patients. Antivir Ther. 2010;15:377-90.

8. Ladha JS, Tripathy MK, Mitra D. Mitochondrial complex I activity is impaired during HIV-1-induced T-cell apoptosis. Cell Death Differ. 2005; 12:1417-28.

9. Cote HC, Brumme ZL, Craib KJ, Alexander CS, Wynhoven B, Ting L, et al. Changes in mitochondrial DNA as a marker of nucleoside toxicity in HIVinfected patients. N Engl J Med. 2002;346:811-20.

10. McComsey G, Bai RK, Maa JF, Seekins D, Wong LJ. Extensive investigations of mitochondrial DNA genome in treated HIV-infected subjects: beyond mitochondrial DNA depletion. J Acquir Immune Defic Syndr. 2005;39:181-8.

11. Lewis W, Dalakas MC. Mitochondrial toxicity of antiviral drugs. Nat Med. 1995;1:417-22.

12. Bannwarth S, Gatignol A. HIV-1 TAR RNA: the target of molecular interactions between the virus and its host. Curr HIV Res. 2005;3:61-71.

13. Gatignol A, Jeang KT. Tat as a transcriptional activator and a potential therapeutic target for HIV-1. Adv Pharmacol. 2000;48:209-27.

14. Lopez-Huertas MR, Callejas S, Abia D, Mateos E, Dopazo A, Alcami J, et al. Modifications in host cell cytoskeleton structure and function mediated by intracellular HIV-1 Tat protein are greatly dependent on the second coding exon. Nucleic Acids Res. 2010;38:3287-307.

15. Lopez-Huertas MR, Mateos E, Del Sanchez CM, Gomez-Esquer F, Diaz-Gil $\mathrm{G}$, Rodriguez-Mora S, et al. The presence of HIV-1 Tat protein second exon delays fas protein-mediated apoptosis in CD4+ T lymphocytes: a potential mechanism for persistent viral production. J Biol Chem. 2013;288:7626-44.

16. Coiras M, Camafeita E, Urena T, Lopez JA, Caballero F, Fernandez B, et al. Modifications in the human T cell proteome induced by intracellular HIV-1 Tat protein expression. Proteomics. 2006;6(Suppl 1):S63-73.

17. Gibellini D, Re MC, Ponti C, Vitone F, Bon I, Fabbri G, et al. HIV-1 Tat protein concomitantly down-regulates apical caspase-10 and up-regulates C-FLIP in lymphoid T cells: a potential molecular mechanism to escape TRAIL cytotoxicity. J Cell Physiol. 2005;203:547-56.

18. Jones M, Olafson K, Del Bigio MR, Peeling J, Nath A. Intraventricular injection of human immunodeficiency virus type 1 (HIV-1) tat protein causes inflammation, gliosis, apoptosis, and ventricular enlargement. J Neuropathol Exp Neurol. 1998;57:563-70.

19. McCloskey TW, Ott M, Tribble E, Khan SA, Teichberg S, Paul MO, et al. Dual role of HIV Tat in regulation of apoptosis in T cells. J Immunol. 1997;158:1014-9.

20. Buccigrossi V, Laudiero G, Nicastro E, Miele E, Esposito F, Guarino A. The HIV-1 transactivator factor (Tat) induces enterocyte apoptosis through a redox-mediated mechanism. PLoS One. 2011;6:e29436.

21. Norman JP, Perry SW, Kasischke KA, Volsky DJ, Gelbard HA. HIV-1 trans activator of transcription protein elicits mitochondrial hyperpolarization and respiratory deficit, with dysregulation of complex IV and 
nicotinamide adenine dinucleotide homeostasis in cortical neurons. J Immunol. 2007;178:869-76.

22. Perry SW, Norman JP, Litzburg A, Zhang D, Dewhurst S, Gelbard HA. HIV-1 transactivator of transcription protein induces mitochondrial hyperpolarization and synaptic stress leading to apoptosis. J Immunol. 2005; 174:4333-44.

23. Leek BT, Mudaliar SR, Henry R, Mathieu-Costello O, Richardson RS. Effect of acute exercise on citrate synthase activity in untrained and trained human skeletal muscle. Am J Physiol Regul Integr Comp Physiol. 2001;280:R441-7.

24. Warburg $\mathrm{O}$. On respiratory impairment in cancer cells. Science. 1956;124:269-70.

25. Warburg O, Gawehn K, Geissler AW. Metabolism of leukocytes. Z Naturforsch B. 1958;13B:515-6.

26. Best TM, Fiebig R, Corr DT, Brickson S, Ji L. Free radical activity, antioxidant enzyme, and glutathione changes with muscle stretch injury in rabbits. J Appl Physiol. 1985;1999(87):74-82.

27. Owen JB, Butterfield DA. Measurement of oxidized/reduced glutathione ratio. Methods Mol Biol. 2010;648:269-77.

28. Anderson S, Bankier AT, Barrell BG, de Bruijn MH, Coulson AR, Drouin J, et al. Sequence and organization of the human mitochondrial genome. Nature. 1981;290:457-65.

29. Falkenberg M, Larsson NG, Gustafsson CM. DNA replication and transcription in mammalian mitochondria. Annu Rev Biochem. 2007;76:679-99.

30. Scarpulla RC. Nuclear control of respiratory chain expression in mammalian cells. J Bioenerg Biomembr. 1997;29:109-19.

31. de la Fuente C, Santiago F, Deng L, Eadie C, Zilberman I, Kehn K, et al. Gene expression profile of HIV-1 Tat expressing cells: a close interplay between proliferative and differentiation signals. BMC Biochem. 2002;3:14.

32. Gutierrez-Aguilar M, Baines CP. Physiological and pathological roles of mitochondrial SLC25 carriers. Biochem J. 2013;454:371-86.

33. Armstrong LC, Saenz AJ, Bornstein P. Metaxin 1 interacts with metaxin 2, a novel related protein associated with the mammalian mitochondrial outer membrane. J Cell Biochem. 1999;74:11-22.

34. Busiello RA, Savarese S, Lombardi A. Mitochondrial uncoupling proteins and energy metabolism. Front Physiol. 2015;6:36.

35. Muehlenbein MP, Watts DP, Whitten PL. Dominance rank and fecal testosterone levels in adult male chimpanzees (Pan troglodytes schweinfurthii) at Ngogo, Kibale National Park, Uganda. Am J Primatol. 2004;64:71-82.

36. Boldogh IR, Pon LA. Mitochondria on the move. Trends Cell Biol. 2007; 17:502-10.

37. Frederick RL, Shaw JM. Moving mitochondria: establishing distribution of an essential organelle. Traffic. 2007;8:1668-75.

38. Campello S, Lacalle RA, Bettella M, Manes S, Scorrano L, Viola A. Orchestration of lymphocyte chemotaxis by mitochondrial dynamics. J Exp Med. 2006;203:2879-86.

39. del Pozo MA, Nieto M, Serrador JM, Sancho D, Vicente-Manzanares M, Martinez C, et al. The two poles of the lymphocyte: specialized cell compartments for migration and recruitment. Cell Adhes Commun. 1998;6:125-33.

40. Griparic L, van der Bliek AM. The many shapes of mitochondrial membranes. Traffic. 2001;2:235-44.

41. Wright G, Terada K, Yano M, Sergeev I, Mori M. Oxidative stress inhibits the mitochondrial import of preproteins and leads to their degradation. Exp Cell Res. 2001;263:107-17.

42. Ryan MT, Hoogenraad NJ. Mitochondrial-nuclear communications. Annu Rev Biochem. 2007;76:701-22.

43. Mor I, Cheung EC, Vousden $\mathrm{KH}$. Control of glycolysis through regulation of PFK1: old friends and recent additions. Cold Spring Harb Symp Quant Biol. 2011;76:211-6.

44. Vegran F, Boidot R, Michiels C, Sonveaux P, Feron O. Lactate influx through the endothelial cell monocarboxylate transporter MCT1 supports an NF-kappaB/IL-8 pathway that drives tumor angiogenesis. Cancer Res. 2011;71:2550-60.

45. Alcami J, de Lain LT, Folgueira L, Pedraza MA, Jacque JM, Bachelerie F, et al. Absolute dependence on kappa B responsive elements for initiation and Tat-mediated amplification of HIV transcription in blood CD4 T lymphocytes. EMBO J. 1995;14:1552-60.

46. Halestrap AP, Price NT. The proton-linked monocarboxylate transporter (MCT) family: structure, function and regulation. Biochem J. 1999;343(Pt 2):281-99.
47. John M, Moore CB, James IR, Nolan D, Upton RP, McKinnon EJ, et al. Chronic hyperlactatemia in HIV-infected patients taking antiretroviral therapy. AIDS. 2001;15:717-23.

48. Divi RL, Haverkos KJ, Humsi JA, Shockley ME, Thamire C, Nagashima K, et al. Morphological and molecular course of mitochondrial pathology in cultured human cells exposed long-term to Zidovudine. Environ Mol Mutagen. 2007;48:179-89.

49. Apostolova N, Gomez-Sucerquia LJ, Moran A, Alvarez A, Blas-Garcia A, Esplugues JV. Enhanced oxidative stress and increased mitochondrial mass during efavirenz-induced apoptosis in human hepatic cells. $\mathrm{Br} J$ Pharmacol. 2010;160:2069-84.

50. Garrabou G, Lopez S, Moren C, Martinez E, Fontdevila J, Cardellach F, et al. Mitochondrial damage in adipose tissue of untreated HIV-infected patients. AIDS. 2011;25:165-70.

51. Morse CG, Voss JG, Rakocevic G, McLaughlin M, Vinton CL, Huber C, et al HIV infection and antiretroviral therapy have divergent effects on mitochondria in adipose tissue. J Infect Dis. 2012;205:1778-87.

52. Chan EY, Qian WJ, Diamond DL, Liu T, Gritsenko MA, Monroe ME, et al. Quantitative analysis of human immunodeficiency virus type 1-infected CD4+ cell proteome: dysregulated cell cycle progression and nuclear transport coincide with robust virus production. J Virol. 2007:81:7571-83.

53. Ringrose JH, Jeeninga RE, Berkhout B, Speijer D. Proteomic studies reveal coordinated changes in T-cell expression patterns upon infection with human immunodeficiency virus type 1. J Virol. 2008;82:4320-30.

54. Coloff JL, Mason EF, Altman BJ, Gerriets VA, Liu T, Nichols AN, et al. Akt requires glucose metabolism to suppress puma expression and prevent apoptosis of leukemic T cells. J Biol Chem. 2011;286:5921-33.

55. Chang DT, Honick AS, Reynolds IJ. Mitochondrial trafficking to synapses in cultured primary cortical neurons. J Neurosci. 2006;26:7035-45.

56. Rivera-Rivera L, Perez-Laspiur J, Colon K, Melendez LM. Inhibition of interferon response by cystatin B: implication in HIV replication of macrophage reservoirs. J Neurovirol. 2012;18:20-9.

57. Pfeiffer T, Schuster S, Bonhoeffer S. Cooperation and competition in the evolution of ATP-producing pathways. Science. 2001;292:504-7.

58. Macintyre AN, Rathmell JC. Activated lymphocytes as a metabolic model for carcinogenesis. Cancer Metab. 2013;1:5.

59. Wang R, Dillon CP, Shi LZ, Milasta S, Carter R, Finkelstein D, et al. The transcription factor Myc controls metabolic reprogramming upon $\mathrm{T}$ lymphocyte activation. Immunity. 2011;35:871-82.

60. Jacobs SR, Herman CE, Maciver NJ, Wofford JA, Wieman HL, Hammen $\mathrm{J}$, et al. Glucose uptake is limiting in $T$ cell activation and requires CD28-mediated Akt-dependent and independent pathways. J Immunol. 2008;180:4476-86.

61. Ferrucci A, Nonnemacher MR, Cohen EA, Wigdahl B. Extracellular human immunodeficiency virus type 1 viral protein $\mathrm{R}$ causes reductions in astrocytic ATP and glutathione levels compromising the antioxidant reservoir. Virus Res. 2012;167:358-69.

62. Jaruga P, Jaruga B, Gackowski D, Olczak A, Halota W, Pawlowska M, et al. Supplementation with antioxidant vitamins prevents oxidative modification of DNA in lymphocytes of HIV-infected patients. Free Radic Biol Med. 2002;32:414-20.

63. Suresh DR, Annam V, Pratibha K, Prasad BV. Total antioxidant capacity-a novel early bio-chemical marker of oxidative stress in HIV infected individuals. J Biomed Sci. 2009;16:61.

64. Torres RA, Lewis W. Aging and HIV/AIDS: pathogenetic role of therapeutic side effects. Lab Invest. 2014;94:120-8.

65. Uzasci L, Nath A, Cotter R. Oxidative stress and the HIV-infected brain proteome. J Neuroimmune Pharmacol. 2013;8:1167-80.

66. Blas-Garcia A, Apostolova N, Esplugues JV. Oxidative stress and mitochondrial impairment after treatment with anti-HIV drugs: clinical implications. Curr Pharm Des. 2011;17:4076-86.

67. Cribbs SK, Guidot DM, Martin GS, Lennox J, Brown LA. Anti-retroviral therapy is associated with decreased alveolar glutathione levels even in healthy HIV-infected individuals. PLoS One. 2014;9:e88630.

68. Mandas A, lorio EL, Congiu MG, Balestrieri C, Mereu A, Cau D, et al. Oxidative imbalance in HIV-1 infected patients treated with antiretroviral therapy. J Biomed Biotechnol. 2009;2009:749575.

69. Chun TW, Carruth L, Finzi D, Shen X, DiGiuseppe JA, Taylor H, et al. Quantification of latent tissue reservoirs and total body viral load in HIV-1 infection. Nature. 1997;387:183-8. 
70. Eriksson S, Graf EH, DahI V, Strain MC, Yukl SA, Lysenko ES, et al. Comparative analysis of measures of viral reservoirs in HIV-1 eradication studies. PLoS Pathog. 2013;9:e1003174

71. Sauce D, Larsen M, Fastenackels S, Pauchard M, Ait-Mohand H, Schneider $L$, et al. HIV disease progression despite suppression of viral replication is associated with exhaustion of lymphopoiesis. Blood. 2011;117:5142-51.

72. Deeks SG. HIV infection, inflammation, immunosenescence, and aging. Annu Rev Med. 2011;62:141-55.

73. Pawelec G, Derhovanessian E, Larbi A, Strindhall J, Wikby A. Cytomegalovirus and human immunosenescence. Rev Med Virol. 2009;19:47-56.

74. Huot J, Houle F, Marceau F, Landry J. Oxidative stress-induced actin reorganization mediated by the p38 mitogen-activated protein kinase/ heat shock protein 27 pathway in vascular endothelial cells. Circ Res. 1997;80:383-92.

75. Minin AA, Kulik AV, Gyoeva FK, Li Y, Goshima G, Gelfand VI. Regulation of mitochondria distribution by RhoA and formins. J Cell Sci. 2006;119:659-70.

76. Gorovoy M, Neamu R, Niu J, Vogel S, Predescu D, Miyoshi J, et al. RhoGDI-1 modulation of the activity of monomeric RhoGTPase RhoA regulates endothelial barrier function in mouse lungs. Circ Res. 2007;101:50-8.

77. Boulter E, Garcia-Mata R, Guilluy C, Dubash A, Rossi G, Brennwald PJ, et al. Regulation of Rho GTPase crosstalk, degradation and activity by RhoGDI1. Nat Cell Biol. 2010;12:477-83.

78. Sklan EH, Serrano RL, Einav S, Pfeffer SR, Lambright DG, Glenn JS. TBC1D20 is a Rab1 GTPase-activating protein that mediates hepatitis C virus replication. J Biol Chem. 2007;282:36354-61.

79. Berkhout B, Jeang KT. trans activation of human immunodeficiency virus type 1 is sequence specific for both the single-stranded bulge and loop of the trans-acting-responsive hairpin: a quantitative analysis. J Virol. 1989;63:5501-4
80. Gaynor RB. Regulation of HIV-1 gene expression by the transactivator protein Tat. Curr Top Microbiol Immunol. 1995;193:51-77.

81. Levy JA. Pathogenesis of human immunodeficiency virus infection. Microbiol Rev. 1993;57:183-289.

82. Gossen M, Bujard H. Tight control of gene expression in mammalian cells by tetracycline-responsive promoters. Proc Natl Acad Sci USA. 1992;89:5547-51.

83. Madore SJ, Cullen BR. Genetic analysis of the cofactor requirement for human immunodeficiency virus type 1 Tat function. J Virol. 1993;67:3703-11.

84. Arenzana-Seisdedos F, Fernandez B, Dominguez I, Jacque JM, Thomas D, Diaz-Meco MT, et al. Phosphatidylcholine hydrolysis activates NF-kappa $B$ and increases human immunodeficiency virus replication in human monocytes and T lymphocytes. J Virol. 1993;67:6596-604.

85. Paulo JA, Kadiyala V, Banks PA, Steen H, Conwell DL. Mass spectrometrybased (GeLC-MS/MS) comparative proteomic analysis of endoscopically (ePFT) collected pancreatic and gastroduodenal fluids. Clin Transl Gastroenterol. 2012;3:e14.

86. Szklarczyk D, Franceschini A, Kuhn M, Simonovic M, Roth A, Minguez P, et al. The STRING database in 2011: functional interaction networks of proteins, globally integrated and scored. Nucleic Acids Res. 2011;39:D561-8.

\section{Submit your next manuscript to BioMed Central and take full advantage of:}

- Convenient online submission

- Thorough peer review

- No space constraints or color figure charges

- Immediate publication on acceptance

- Inclusion in PubMed, CAS, Scopus and Google Scholar

- Research which is freely available for redistribution

Submit your manuscript at

www.biomedcentral.com/submit

C Biomed Central 